\title{
The WTO's Dispute Settlement Body as a Voice Mechanism
}

\author{
Joshua Paine \\ Max Planck Institute Luxembourg for Procedural Law, Luxembourg \\ josh.painer@gmail.com
}

\begin{abstract}
This article focuses on the World Trade Organization's (WTO) Dispute Settlement Body (DSB) - the diplomatic body, consisting of representatives of WTO members, that administers the dispute settlement system. Focusing on the WTO, the article provides one perspective on the relationship between international tribunals and the political bodies that oversee the governance of such tribunals. Specifically, I argue that the DSB operates as an important 'voice' mechanism, which enables members to provide regular feedback to WTO adjudicators, and helps sustain the internal legitimacy of WTO adjudication. However, the DSB can also be used in ways that undermine judicial independence. In short, the DSB is a key site where the tension plays out between WTO adjudicators' independence from members, and control by, and accountability to, members. The episodes examined in detail to develop this argument are the crisis of a generation ago over amicus curiae briefs, and the ongoing crisis over Appellate Body appointments.
\end{abstract}

\section{Keywords}

Appellate Body - Dispute Settlement Body - exit, voice and loyalty - judicial independence - judicial accountability - control mechanisms - internal legitimacy

* Senior Research Fellow, Max Planck Institute Luxembourg for Procedural Law. For comments on prior drafts I thank Hélène Ruiz Fabri, Giorgio Sacerdoti and Stephan Schill. I also benefited from the comments of participants at a workshop on Sociological Perspectives on International Tribunals, Max Planck Institute Luxembourg, November 2018, and an internal seminar at the Institute. This article was largely finalised based on information available at 2 August 2019. Where possible, a small number of subsequent references have been added during copy-editing of the article in October 2019. 
Despite the vast amount of writing on dispute settlement in the World Trade Organization (WTO), surprisingly little attention has been paid to the Dispute Settlement Body (DSB) specifically. ${ }^{1}$ The DSB is the diplomatic body, consisting of representatives of all WTO members, with responsibility, among other matters, for establishing panels, adopting panel and Appellate Body (AB) reports, and authorising the suspension of concessions. As these actions are subject to the reverse consensus procedure, their outcome is in practice a foregone conclusion. However, it would be wrong for this reason to dismiss the DSB as a mere formality, or venue for cheap talk, not worthy of further analysis. Instead, this article posits that having the DSB, where WTO members can, among other things, express their views on adjudicators' decisions and debate issues of systemic concern, may serve a number of important functions within the legal and political processes of the WTO.

This article is a targeted intervention, focused on the WTO, into broader questions concerning the relationship between international tribunals and diplomatic bodies, and adjudicatory and political processes. The relationship between the $\mathrm{AB}$ and panels, on the one hand, and the $\mathrm{DSB}$, is an example of an issue that also arises in other international legal contexts - namely the relationship between international tribunals and the political bodies responsible

1 Within English language literature the small number of contributions that focus on the DSB's activities include: Cosette D Creamer and Zuzanna Godzimirska, 'Deliberative Engagement within the World Trade Organization: A Functional Substitute for Authoritative Interpretations' (2016) 48 NYU J Intl L \& Pol 413. Cosette D Creamer and Zuzanna Godzimirska, '(De)Legitimation at the WTO Dispute Settlement Mechanism' (2016) 49 Vand J Transnatl L 275. Zuzanna Godzimirska, 'Delegitimation of Global Courts: Lessons from the Past' in Avidan Kent, Nikos Skoutaris and Jamie Trinidad (eds), The Future of International Courts: Regional, Institutional and Procedural Challenges (Routledge 2019) 123. Bozena Mueller-Holyst, 'The WTO Dispute Settlement Body: Procedural Aspects of Its Operation' in Gabrielle Marceau (ed), A History of Law and Lawyers in the GATT/WTO: The Development of the Rule of Law in the Multilateral Trading System (CUP 2015) 264. Bozena Mueller-Holyst, 'The Role of the Dispute Settlement Body in the Dispute Settlement Process' in Rufus Yerxa and Bruce Wilson (eds), Key Issues in WTO Dispute Settlement: The First Ten Years (CUP 2005) 25. Tomer Broude, International Governance in the WTO:Judicial Boundaries and Political Capitulation (Cameron May 2004) 188-202. Steve Charnovitz, 'Judicial Independence in the World Trade Organization' in Laurence Boisson de Chazournes, Cesare PR Romano and Ruth Mackenzie (eds), International Organizations and International Dispute Settlement: Trends and Prospects (Transnational Publishers 2002) 219. William J Davey, 'WTO Dispute Settlement: Segregating the Useful Political Aspects and Avoiding "Over-Legalization"' in Marco Bronckers and Reinhard Quick (eds), New Directions in International Economic Law: Essays in Honour of John HJackson (Kluwer Law International 2000) 291. 
for overseeing the governance of such tribunals. ${ }^{2}$ Not all of those political bodies are as formalised as the DSB, being a separate organ of the relevant international organization, nor meet as frequently to consider the operation of the relevant tribunal. ${ }^{3}$ Nevertheless, as Neils Blokker has noted, certain common features can be identified, such as that political governance bodies are typically made up of representatives of the States parties to the relevant international tribunal, that what matters is the decisions (or failure to take decisions) by the governance body collectively, and that, to varying degrees, there are decision-making and procedural rules that the governance body must observe. ${ }^{4}$

A common and crucial issue that arises is that such political governance bodies are a key site where the tension plays out between the independence of international tribunals and their accountability to member States. ${ }^{5}$ As we will see in relation to the DSB, States may use political governance bodies in ways that undermine judicial independence, a risk that others have highlighted in relation to other international tribunals. ${ }^{6}$ At the same time, States parties have a legitimate interest in how the international tribunals they support operate, including because of the significant influence that such tribunals often have over the development of relevant areas of international law. ${ }^{7}$ Furthermore,

2 A useful initial attempt to address this issue is Niels Blokker, "The Governance of International Courts and Tribunals: Organizing and Guaranteeing Independence and Accountability' in Andreas Follesdal and Geir Ulfstein (eds), The Judicialization of International Law: A Mixed Blessing? (OUP 2018) 26. Blokker terms such political bodies 'international judicial governance institutions' (ibid 27).

3 Blokker notes that there appear to be three basic legal models that the relevant political organs follow. First, they may be an organ of the relevant international organization, second they may be an organ created by the relevant treaty, or thirdly they may be a more loosely organized (even ad hoc) gathering of the States parties to the relevant tribunal (ibid 34-35).

4 ibid $33-35$.

5 ibid 37-39. The concepts of independence and accountability are analysed below Part 3.3.

6 An important recent analysis of this point in relation to the Assembly of State Parties (ASP) to the International Criminal Court (ICC) is Hannah Woolaver and Emma Palmer, 'Challenges to the Independence of the International Criminal Court from the Assembly of States Parties' (2017) 15 JICJ 641. See also Blokker (n 2) 27-33 (discussing recent examples from the Tribunal of the Southern African Development Community (SADC Tribunal), the ICC, and the International Court of Justice (ICJ)). Dominic Raab and Hans Bevers, 'The International Criminal Court and the Separation of Powers' (2006) 3 IOLR 93, 108-109, 135 (noting this issue in relation to the ICC). Paul Mahoney, 'The International Judiciary - Independence and Accountability' (2008) 7 LPICT 313, 315, 319, 334-35. Ruth Mackenzie and Philippe Sands, 'International Courts and Tribunals and the Independence of the International Judge' (2003) 44 HILJ 271, 283-284.

7 Raab and Bevers (n 6) 135 (making a similar observation in relation to the ICC); Blokker (n 2 ) 38-39. 
on the international plane judicial independence is complicated by the fact that international tribunals ultimately depend upon the 'political fact' of a reasonable degree of ongoing support from member States. ${ }^{8}$

More specifically, this article analyses the DSB's role as a 'voice' mechanism within the WTO. I use this term in the sense of the framework of 'exit, voice and loyalty', developed by Albert Hirschman as a way of conceptualising member dissatisfaction with the performance of an organization. ${ }^{9}$ While this framework will be explained further below, a core aspect of Hirschman's theory is that members who are dissatisfied with an organization's performance can either exercise 'voice', by publicly articulating their dissatisfaction and attempting to reform the organization from within, or exit the organization. ${ }^{10}$ Furthermore, Hirschman suggests that effective voice mechanisms can sometimes act as a substitute for exit from an organization. ${ }^{11}$ My basic argument is that the DSB, as a voice mechanism, provides members with a centralised forum for providing regular feedback to WTO adjudicators and helps sustain the internal legitimacy of WTO adjudication vis-à-vis members. ${ }^{2}$ However, key episodes where the DSB has been used as voice mechanism also highlight how diplomatic bodies that oversee international tribunals can be used in ways that undermine judicial independence. In short, there is a balance to be struck between maintaining ongoing political buy-in from member States and safeguarding judicial independence.

8 Charnovitz (n 1 ) 239. See also Yuval Shany, Assessing the Effectiveness of International Courts (OUP 2014) 109.

9 Albert O Hirschman, Exit, Voice and Loyalty: Responses to Decline in Firms, Organizations, and States (Harvard University Press 1970).

10 ibid 4, 16, 30.

11 ibid $37-38$.

12 Internal legitimacy is generally understood as focused on regime insiders, such as in the WTO the representatives of members. It is a form of sociological legitimacy, judged according to whether regime insiders see WTO adjudicators as having the right to rule: see eg Harlan Grant Cohen and others, 'Legitimacy and International Courts - A Framework' in Nienke Grossman and others (eds), Legitimacy and International Courts (CUP 2018) 1, 4-5; Joost Pauwelyn, 'Who Decides Matters: The Legitimacy Capital of WTO Adjudicators versus ICSID Arbitrators' in Nienke Grossman and others (eds), Legitimacy and International Courts (CUP 2018) 216, 217-19, 224-28 (suggesting in relation to WTO adjudication '[i]nternal legitimacy weighs heavier than external legitimacy' and highlighting the DSB as an important mechanism for providing member feedback to WTO adjudicators); Joseph HH Weiler, "The Rule of Lawyers and the Ethos of Diplomats Reflections on the Internal and External Legitimacy of WTO Dispute Settlement' (2001) 35 JWT 191, 193; Reto Malacrida and Gabrielle Marceau, 'The WTO Adjudicating Bodies' in Robert Howse and others (eds), The Legitimacy of International Trade Courts and Tribunals (CUP 2018) 20-21. 
In order to develop this argument, I consider in detail the two most significant episodes of the DSB being used as a voice mechanism in the WTO's history: the widespread member backlash over amicus curiae briefs a generation ago, and the blocking by the United States of $\mathrm{AB}$ (re)appointments from 2016 to present. In relation to the current crisis, the framework of exit, voice and loyalty helps explain States' behaviour. For example, as Hirschman's framework would suggest, the United States, while blocking all AB (re)appointments, has used DSB meetings to communicate concerns with the AB's performance, which have effectively been laid out as demands that must be met, in order for the United States to remove its block. Relatedly, to varying degrees, all of proposed solutions to the current crisis, put forward by a wide range of WTO members since mid-2018, respond to the concerns raised by the United States, thus suggesting that the latter's exercise of voice has been fairly effective.

To be sure, this article does not treat every potential function of the DSB. The DSB also performs a function of monitoring the implementation of adopted ruling and recommendations by members who are found to be in non-compliance. ${ }^{13}$ This aspect of the DSB's work raises important questions about whether the surveillance system, as it is currently designed, is effective at generating reputational costs, and thus incentives to comply, as has often been asserted in the literature. ${ }^{14}$ The compliance-monitoring function of the

13 WTO, Understanding on Rules and Procedures Governing the Settlement of Disputes (DSU), Annex 2 of Agreement Establishing the World Trade Organization (opened for signature 15 April 1994, entered into force 1 January 1995) 1867 UNTS 3 (WTO Agreement), arts 21.6 and 22.8. Under art 21.6, 'The DSB shall keep under surveillance the implementation of adopted recommendations or rulings', and any member can raise the issue of implementation of adopted recommendations or rulings in the DSB. Unless the DSB decides otherwise, the issue of implementation of recommendations or rulings is placed on the DSB's agenda six months after the reasonable period of time for compliance is established, and the issue remains on the DSB's agenda at each meeting until the issue of implementation is resolved: art 21.6. The non-complying member has to provide a 'status report' on the progress made towards implementation at least 10 days prior to each DSB meeting at which the issue remains on the DSB's agenda: art 21.6.

14 See especially Cherie O'Neal Taylor, 'Beyond Retaliation' (2017) 38 Northwest J Intl L \& Bus 55, 117 (detailed study of all disputes that reached the retaliation stage, concluding that 'the surveillance system has played no role in the resolving [of] any' such disputes). O'Neal Taylor proposes reforms to the surveillance system concerning the process by which the DSB monitors compliance, through the DSB creating an independent report on compliance, rather than relying on the responding member's notifications, and a peer review body to scrutinise compliance: $133^{-135}$. For an assertion that the DSB's compliancemonitoring role creates a 'forum for the "mobilization of shame"' see Pieter Jan Kuijper, 'WTO Institutional Aspects' in Daniel Bethlehem and others (ed), The Oxford Handbook of International Trade Law (OUP 2009) 79, 123. There is limited reporting of interviewbased evidence that in broad-brush terms supports the idea that the surveillance 
DSB is not addressed in this article because it largely concerns disputes over (non-)compliance between WTO members, and raises a distinct debate about what may or may not push members to comply with their obligations. ${ }^{15}$ In contrast, the voice function, which I focus on, is concerned with the relationship between WTO adjudicators and members as principals, and the tension between the independence of international tribunals and their accountability to member States.

There are also some limited suggestions in existing literature that the DSB, through its regular meetings, may serve as a mechanism for socialization and learning among members, particularly those that are less active in the dispute settlement system. ${ }^{16}$ While this suggestion is worthy of further investigation, including in light of what is already known about socialization through the work of the WTO's committees, ${ }^{17}$ this article does not attempt to develop this claim. This reflects that the socialization function is difficult to pinpoint without having conducted interviews with members' Geneva-based representatives. Finally the DSB performs certain other tasks that may be understood as simply administering the Dispute Settlement Understanding (DSU). These include establishing panels, approving names put forward by members for inclusion on the WTO's indicative list of panellists, and providing annual updates on the activity of the dispute settlement system. ${ }^{18}$ The administrative function is not treated separately here because to the extent that it involves

function, as currently configured, generates reputational costs and incentives to comply: see Joseph A Conti, Between Law and Diplomacy: The Social Contexts of Disputing at the World Trade Organization (Stanford University Press 2011) 81-83; Geraldo Vidigal, 'Why Is There So Little Litigation Under Free Trade Agreements? Retaliation and Adjudication in International Dispute Settlement' (2017) 20 JIEL 927, 941.

15 Cosette Creamer and Zuzanna Godzimirska, 'The Rhetoric of Legitimacy: Mapping Members' Expressed Views on the WTO Dispute Settlement Mechanism' (2015) iCourts Working Paper No. 16, 11-12 (suggesting the intended audiences of statements regarding implementation are usually other members or possibly home constituencies) $<$ https:// papers.ssrn.com/sol3/papers.cfm?abstract_id $=2560780>$ accessed 2 August 2019. This is not to say that disputes over compliance are merely bilateral affairs; arguably, noncompliance is an affront to the entire membership: see eg Vidigal (n 14) 935.

16 Creamer and Godzimirska, 'Deliberative Engagement' (n 1) $45^{8}$ (finding in interviews that a number of developing country member representatives likened attendance at DSB meetings to third party participation in terms of being a mechanism for learning about WTO dispute settlement); Gregory Shaffer, Manfred Elsig and Sergio Puig, 'The Extensive (but Fragile) Authority of the WTO Appellate Body' (2016) 79 LCP 237, 247.

17 Andrew Lang and Joanne Scott, 'The Hidden World of WTO Governance' (2009) 20 EJIL 575, 604-5, 614; Robert Wolfe, 'See You in Geneva? Legal (Mis)Representations of the Trading System' (2005) 11 EJIR 339, 353, $35^{8}$.

18 DSU arts 6.1 and 8.4. 'Dispute Settlement Body Annual Report (2018)' (30 November 2018) $\mathrm{WT} / \mathrm{DSB} / 76$. 
any controversy, it is because it has moved into the category of voice. For example, members occasionally state at the time of the establishment of a panel that they do not think the WTO is competent to adjudicate on the issues concerned, which sends a strong signal to adjudicators regarding the sensitivity of the issues in dispute. ${ }^{19}$ Likewise, within the DSB's role of overseeing the operation of the dispute settlement system, WTO members have sometimes raised concerns about delays existing within the system and called upon the WTO Secretariat to provide an explanation. ${ }^{20}$ Again, this is a prime example of the voice function.

Structurally, this article proceeds as follows. Part 2 briefly recaps the institutional position of the DSB, as it is important to set out clearly this background. Part 3, which develops the conceptual side of my argument, unpacks Hirschman's framework and its application to the WTO, the persistent imbalance between the WTO's legislative and adjudicatory arms, and the concepts of judicial independence and accountability. Part 4 analyses the two key instances where the DSB has been used as a voice mechanism on a sustained basis: the crisis of a generation ago over amicus curiae briefs, and the ongoing crisis over AB appointments. Part 5 concludes.

\section{The Institutional Position of the DSB}

Although the DSB is a distinct entity created by the DSU, it is simply 'an emanation, or an alter ego' of the WTO's General Council, the plenary diplomatic body composed of representatives of all WTO members, which meets as the DSB when it administers the dispute settlement system. ${ }^{21}$ The DSB is responsible for administering the dispute settlement system, including establishing panels, adopting panel and AB Reports, monitoring the implementation of rulings and recommendations, and authorising the suspension of concessions. ${ }^{22}$ At the level of formal legal design, both panels and the $\mathrm{AB}$ have a status that

19 See eg DSB, Minutes of Meeting of 22 November 2017, WT/DSB/M/404, paras 3.3-3.13.

20 See eg DSB, Minutes of Meeting of 31 August 2015, WT/DSB/M/367, paras 13.2-13.23.

21 Peter Van den Bossche and Werner Zdouc, The Law and Policy of the World Trade Organization: Texts, Cases and Materials (4th ed, CUP 2017) 133, 209. WTO Agreement art IV:3; DSU art 2.1. The General Council is the highest decision-making body in the WTO besides the Ministerial Conference that meets every two years: WTO Agreement, art IV:1-2. The DSB has its own Chairperson and operates on a slightly modified version of the rules of procedure of the General Council: 'Rules of Procedure for the Dispute Settlement Body' (19 January 1997) WT/DSB/9. 
is 'clearly subsidiary to that of the' DSB. ${ }^{23}$ Indications of this subsidiary status include that panel and $\mathrm{AB}$ reports only become binding for the disputing parties, andlegally persuasive for otherWTO members, once adopted by the DSB; ${ }^{24}$ that panels have the function 'to assist the DSB in discharging its responsibilities' by making 'findings as will assist the DSB in making the recommendations or in giving the rulings provided for in the covered agreements'; $; 5$ and that the DSB must establish panels. ${ }^{26}$ Each of the key decisions that the DSB must take in any dispute (establishment of a panel, adoption of a report, authorising the suspension of concessions) is subject to the so-called 'reverse consensus' rule, whereby the relevant decision is taken unless the DSB decides by consensus not to do so, which in practice is extremely unlikely to occur. ${ }^{27}$

However, the default rule in the DSB is that decisions are taken by consensus $^{28}$ and this applies to certain key decisions that the DSB must make, such as the appointment of $\mathrm{AB}$ members, ${ }^{29}$ and the adoption of an agenda which enables meetings to proceed. ${ }^{30}$ In other words, these decisions are subject to being blocked by a recalcitrant member. ${ }^{31}$ Importantly, at key points

23 Lorand Bartels, 'The Separation of Powers in the WTO: How to Avoid Judicial Activism' (2004) 53 ICLQ 861, 864; Broude (n 1) 144-146 (Panels and the AB 'are organizational subjects of the Dispute Settlement Body'); Debra P Steger, 'The Founding of the Appellate Body' in Gabrielle Marceau (ed), A History of Law and Lawyers in the GATT/WTO: The Development of the Rule of Law in the Multilateral Trading System (CUP 2015) 447, 448 (AB 'remains a tribunal under the direct supervision of the DSB').

24 WTO,Japan - Taxes on Alcoholic Beverages, Report of the Appellate Body (4 October 1996) $\mathrm{WT} / \mathrm{DS} 8 / \mathrm{AB} / \mathrm{R}, \mathrm{WT} / \mathrm{DS} 10 / \mathrm{AB} / \mathrm{R}, \mathrm{WT} / \mathrm{DS} 11 / \mathrm{AB} / \mathrm{R}, 14$ (regarding panel reports); WTO, United States - Import Prohibition of Certain Shrimp and Shrimp Products (Article 21.5 Malaysia), Report of the Appellate Body (22 October 2001) WT/DS58/AB/RW, para 109 (regarding $\mathrm{AB}$ reports).

25 DSU arts 11 and 7.1. The AB is mandated to hear appeals on issues of law and legal interpretations from panel reports (under DSU art 17.6) and its role can be viewed as ensuring that panel reports are legally correct: Bartels (n 23) 864 .

26 Broude ( $\mathrm{n} 1$ 1) 145 (also noting it is the DSB, not the AB or panels, that is entrusted with administering the DSU). Further indications that panels and the $\mathrm{AB}$ are subordinate to the WTO's political organs are noted in Broude (n 1 ) 296-7. Due to these political inputs in the dispute settlement process, at the level of formal legal design the WTO dispute settlement process could be characterised as a 'quasi-judicial one': Broude (n 1) 151 and fn 58 .

27 DSU arts 6.1, 16.4, 17.14, and 22.6-7. A reverse consensus is highly unlikely because there will always be at least one member, the complainant, who is in favour of the relevant decision being taken.

28 DSU art 2.4. As clarified in footnote 1, consensus requires that no member present at the relevant meeting formally objects to the proposed decision.

29 DSU art 17.2.

$30 \quad$ Mueller-Holyst, 'Procedural Aspects' (n 1) 270-71.

31 Recent examples of the blocking of $\mathrm{AB}$ appointments are discussed below in Part 4.2. There are previous instances where members have blocked the adoption of an agenda. 
where the DSB is involved in disputes (e.g. adoption of reports or surveillance of implementation), all WTO members have a right to express their views, whether or not they are a party to the relevant dispute. ${ }^{32}$ Statements made in DSB meetings do not generate legal obligations for the members making the statements, ${ }^{33}$ nor do such statements bind WTO adjudicators. ${ }^{34}$ Finally, the DSB has a right to be informed of certain matters, such as when panels or the $\mathrm{AB}$ cannot submit their reports within the relevant deadlines. ${ }^{35}$ Apart from limited rights to be informed, once a panel is established, the DSB does not have a role in the dispute resolution process until a report of the panel (or the $A B$, if there is an appeal) has been issued and is put on the DSB's agenda for adoption. ${ }^{36}$

The DSB holds both regular monthly meetings and additional meetings where required to meet the deadlines imposed by the DSU. ${ }^{37}$ Additionally, the DSB in Special Session meets to discuss potential reforms to the DSU. A significant empirical study by Cosette Creamer and Zuzanna Godzimirska found that in the 340 DSB meetings held up to the end of 2013, WTO members made some 9,833 statements, or an average of 28.92 statements per meeting. ${ }^{38}$ While most WTO members send a representative to all DSB meetings, differences in the sizes of the Geneva-based delegations of members mean that smaller and less well-resourced members do not necessarily systematically attend meetings or follow all agenda items. ${ }^{39}$

For example, during the $E C$ - Bananas dispute several members objected to the adoption of the DSB's agenda, because it included a request by the United States to suspend concessions before there had been a finding of non-compliance under art 21.5 of the DSU. When the meeting was resumed three days later, the Chairman decided that the agenda would be adopted and the disagreement could be addressed in debate over the relevant agenda item. The European Communities expressed its view that a DSB decision to adopt the agenda had to be taken by consensus, and this had been overruled by the Chairman: see DSB, Minutes of Meeting Held on 25, 28 and 29 January and 1 February 1999, WT/ $\mathrm{DSB} / \mathrm{M} / 54,2-10$.

32 DSU arts 16.3-4, 17.14, and 21.6.

33 WTO, United States - Continued Suspension of Obligations in the EC - Hormones Dispute, Report of the Appellate Body (16 October 2008) WT/DS320/AB/R, paras 398-99.

34 Creamer and Godzimirska, 'Deliberative Engagement' (n 1) 423; Charnovitz (n 1 ) 237.

35 DSU arts 12.9 and 17.5. See also art 21.3 (DSB to be informed of member's intentions regarding implementation within thirty days of report adoption).

36 Mueller-Holyst, 'Procedural Aspects' (n 1 ) 267.

37 Van den Bossche and Zdouc (n 21) 210.

38 Creamer and Godzimirska, '(De)Legitimation' (n 1 ) 286. For similar findings across a different time period see Shaffer, Elsig and Puig (n 16) 259.

39 Creamer and Godzimirska, 'Deliberative Engagement' (n 1) 438. Shaffer, Elsig and Puig (n 16) 259. 
Although DSB meetings are not public, the statements made by WTO members are recorded in minutes, kept by the Secretariat, which are regarded as verbatim records, and are made public on the WTO website 45 days after they are circulated to members. ${ }^{40}$ In their interviews with WTO delegations, Creamer and Godzimirska found that in relation to those member statements concerning the adoption of panel or AB reports, 'the intended audience ... was the system as a whole (the Secretariat, panellists, and the Appellate Body), with the purpose being to place on the record a government's views on legal interpretations or procedural decisions' ${ }^{41}$ It is also noteworthy that '[r]epresentatives from the Legal Affairs Division of the Secretariat and the Appellate Body Secretariat sit in on DSB meetings', and in the interviews reported by Creamer and Godzimirska 'WTO officials confirmed that these two bodies pay particular attention to systemic and procedural issues raised by Members' in DSB meetings. ${ }^{42}$ In sum, the DSB is a highly active body, whose meetings are taken very seriously by WTO members, adjudicators and the Secretariat, even if there has been a tendency among commentators to dismiss the DSB's role as a formality or 'a superfluous vestige' of the General Agreement on Tariffs and Trade (GATT)'s more diplomatic dispute settlement system. ${ }^{43}$

\section{3}

\section{The DSB as a Voice Mechanism: Conceptual Background}

This Part develops the conceptual side of my argument that the DSB is a voice mechanism that provides a centralised forum for WTO members to provide feedback to WTO adjudicators. As flagged above, a related claim of this article is that while the voice function of the DSB helps sustain the internal legitimacy of WTO adjudication vis-à-vis members, it can also be used by members in ways that undermine judicial independence. Specifically, this Part addresses Hirschman's framework and its application to the WTO; the de facto imbalance between the WTO's legislative and adjudicatory arms; and the concepts of judicial independence and accountability.

\footnotetext{
40 Creamer and Godzimirska, '(De)Legitimation' (n 1) 285-286; WTO, 'Procedures for the Circulation and Derestriction of WTO Documents', Decision of 14 May 2002, WT/L/452, para 2(c). The French and Spanish versions of the minutes are distributed more slowly because of the need for translation.

41 Creamer and Godzimirska, '(De)Legitimation' (n 1 ) 291.

42 Creamer and Godzimirska, 'Deliberative Engagement' (n 1 ) 448.

43 Vidigal (n 14) 935.
} 


\subsection{Exit, Voice and Loyalty and Its Application to the WTO}

In referring to 'voice', I borrow this idea from Hirschman's framework of 'exit, voice and loyalty', developed as a way of conceptualising member responses to dissatisfaction with the performance of an organization. ${ }^{44}$ Relevantly to the current crisis facing the WTO, Hirschman suggested that deteriorations in the performance of an organization are subjectively determined, and would differ between members. Accordingly, a perceived deterioration could simply reflect a dissatisfied member's 'increasing disagreement within the organization's policies' 45 Hirschman contends that members who are dissatisfied with an organization's performance can either exercise 'voice', by publicly articulating their dissatisfaction and attempting to reform the organization from within, or exit the organization, which may also cause the organization to respond to the dissatisfied members' demands. ${ }^{46}$ The framework suggests that in organizations where there are limited options for exit, voice is the dominant means for members to express dissatisfaction. ${ }^{47}$ Furthermore, effective voice mechanisms can provide an alternative to exit. ${ }^{48}$ Loyalty is important because members who feel loyalty to an organization are more likely to opt for exercising voice, and attempting to reform the organization from within, than to exit the organization. ${ }^{49}$ Joseph Weiler, in a seminal account of the interaction of judicial and political forces in the early European Community, summarised Hirschman's key insight as: 'a stronger "outlet" for Voice reduces pressure on the Exit option and can lead to more sophisticated processes of self-correction. By contrast, the closure of Exit leads to demands for enhanced Voice. 50 Those who have applied Hirschman's framework to international organizations highlight that a credible threat of exit (or actual exit) may be used by dissatisfied

44 Hirschman (n 9) 1. Hirschman, writing at the intersection of politics and economics, sought to develop a framework that could explain both consumer responses to declines in the performance of firms and member responses to poor performance in non-economic organizations: 1 .

45 ibid 87. See also $48-49$.

46 ibid 4, 16, 30.

47 ibid $17,33,76$.

48 ibid $37-38$.

49 ibid $77-80$. Loyalty is an underdeveloped aspect of Hirschman's framework. For a perspective that further develops this concept for the international relations context see Lauge N Skovgaard Poulsen, 'Loyalty in World Politics' (draft on file with author).

$50 \quad$ Joseph HH Weiler, 'The Transformation of Europe' (1991) 100 Yale L J 2403, 2411. Applying this idea, Weiler argued that "[w]hen the international law is "real," when it is "hard" in the sense of being binding ... and when there are effective legal remedies to enforce it' - ie where exit is foreclosed - States will be concerned to control the process through which the law emerges: $2423-2427$. 
members to reshape the organization (or a rival organization) in line with their preferences. ${ }^{51}$

Joost Pauwelyn has applied Hirschman's framework to the WTO, suggesting that the WTO is an organization characterised by 'low exit and high voice', because the shift from the GATT to the WTO, among other things, saw members lose the ability to block the dispute settlement process or resort to self-help, as well as a major increase in the scope of legal disciplines..$^{52}$ Formally, of course, WTO members can exit the Organization on six months' notice. ${ }^{53}$ In practice, however, withdrawal from the WTO is an option with limited credibility because it would be costly', ${ }^{\prime 4}$ given the preferential treatment that membership brings within a large club of members, and the wide range of matters that are regulated by the WTO. Pauwelyn emphasised that the WTO's greater emphasis on consensus decision-making in various respects, compared to the organizational rules that prevailed in the GATT, increased the opportunities for voice, participation, and potential veto by individual WTO members, ${ }^{55}$ and that these enhanced voice mechanisms were the precondition for members accepting a more legalized dispute settlement process. ${ }^{56}$ More generally, Pauwelyn suggested that high levels of voice, in the form of political inputs and contestation, 'are an absolute requirement' for sustaining high levels of legalization, and organizations without a sufficient degree of voice risk losing support. ${ }^{57}$

Similarly to this article, Pauwelyn emphasised the importance of the 'political control that the DSB ... exercises over dispute settlement', describing the DSB as 'the umbilical cord between the political and judicial branch ... a crucial interface and forum of contestation or voice to which both panels and the

51 Laurence R Helfer, 'Exiting Treaties' (2005) 91 Va L Rev 1579, 1583-1584, 1588. Richard H Steinberg, 'In the Shadow of Law or Power? Consensus-Based Bargaining and Outcomes in the GATT/WTO' (2002) 56 Intl Org 339, 349, 356-357. For a thoughtful application of Hirschman's framework to the investment treaty regime see Anna T Katselas, 'Exit, Voice, and Loyalty in Investment Treaty Arbitration' (2014) 93 Neb L Rev 313.

52 Joost Pauwelyn, 'The Transformation of World Trade' (2005) 104 Mich L Rev 1, 5, 24-25; See also Joost Pauwelyn, 'The Sutherland Report: A Missed Opportunity for Genuine Debate on Trade, Globalization and Reforming the WTO' (2005) 8 JIEL 329, 337-346; DSU art 23. WTO Agreement, art XV:1.

54 Richard H Steinberg, 'Judicial Lawmaking at the WTO: Discursive, Constitutional, and Political Constraints' (2004) 98 AJIL 247, 267.

55 See Pauwelyn, 'Transformation' (n 52 ) 26-28.

56 ibid $30-32,52$.

57 ibid $5,33-34$. 
Appellate Body are most receptive.,58 Likewise, Richard Steinberg has noted that members' statements in the DSB that criticise AB decisions, particularly where they are widespread, can bring member discontent to the attention of the $\mathrm{AB}$ and flag that 'it may be operating near or over the edge of its strategic space. 59 'Strategic space' is the idea that as well as constraints on adjudicators arising from legal discourse and relevant constituent instruments, adjudicators are subject to constraints arising from the need for their decisions to be broadly politically acceptable to member States. ${ }^{60}$

\subsection{The WTO's 'Missing Legislator'61}

A key contextual factor that conditions the DSB's role as a potentially important voice mechanism, and lies at the heart of the current crisis over $\mathrm{AB}$ appointments, is the imbalance between legislative and judicial power within the WTO. ${ }^{62}$ Such an imbalance arises because the WTO features in practice, if not design, a very strong judicial arm, given, inter alia, a wide-ranging grant of compulsory jurisdiction, a centralised appellate mechanism, and the adoption

$5^{8}$ ibid 49; Similarly James McCall Smith, 'WTO Dispute Settlement: The Politics of Procedure in Appellate Body Rulings' (2003) 2 WTR 65, 75 (suggesting that the AB works to build a consistent body of jurisprudence but is also 'eager to avoid adverse political responses by WTO member states that would tend to undermine' its authority). Kuijper (n 14) 122 ('the discussions in the DSB on the occasion of the adoption of panel reports, especially if they are generalized among the Members, offer precious indications to the Appellate Body what the prevailing mood is among the membership and thus can help it in improving its reasoning in future cases'). But see Pauwelyn (n 12) 227-228 (suggesting that such '[i]nformal steering' through the DSB has become more difficult with greater diversity among the WTO membership). Broude (n 1) 197-202 (suggesting that various institutional features of the WTO, including the possibility of criticising reports in the DSB, create a comparatively high potential for 'immediate reactive capacity' by political organs, but in practice '[p]olitical communications to the judicial elements have also proved futile in their capacity to alter judicial decisions.').

59 Steinberg ( $\mathrm{n}_{54}$ ) 266. See also Tom Ginsburg, 'Bounded Discretion in International Judicial Lawmaking' (2005) 45 Va J Intl L 631, 666 (noting that where an international tribunal is embedded in a broader international organization, meetings of the States parties may enable States to 'signal displeasure in a formal way' and exert informal control over the tribunal). Laurence R Helfer and Anne-Marie Slaughter, 'Why States Create International Tribunals: A Response to Professors Posner and Yoo' (2005) 93 CLR 899, 952.

6o Steinberg (n 54) 249; Helfer and Slaughter ( $\mathrm{n}$ 59) 942-943; Smith (n 58) 74-75.

61 This term is borrowed from Armin von Bogdandy, 'Law and Politics in the WTO Strategies to Cope with a Deficient Relationship' (2001) 5 Max Planck YB UN L 6og, 651.

62 It is this imbalance, given the inability to agree on authoritative interpretations or amendments, that arguably makes statements made by WTO members in DSB meetings an important source of information for WTO adjudicators about the membership's preferences: Creamer and Godzimirska, 'Deliberative Engagement' (n 1) 421, 451-452. 
of reports by reverse consensus. This exists alongside a largely inactive negotiating arm, due to the strict adherence in practice to the principle of consensus decision-making, combined with a large and diverse membership. ${ }^{63}$ This has prevented political correction through authoritative interpretations or treaty amendments. ${ }^{64}$ This imbalance has become a greater problem over time, as the body of $\mathrm{AB}$ jurisprudence has grown, in ways that are argued by some to depart from members' original intentions, and as WTO rules have failed to keep up with changes in the global economy that affect the existing balance of rights and obligations. ${ }^{65}$

For some, the way to address this imbalance is not to weaken the judicial arm of the WTO but to strengthen its political processes. ${ }^{66}$ In contrast, others suggest that it is unlikely that WTO members will be willing to bound by more robust political processes that involve a departure from the principle of consensus, given the risk of being outvoted. ${ }^{67}$ From this perspective, the answer to the imbalance are reforms that scale back the law-making influence of

63 See eg Broude (n 1) 151, 283, 291-293 313-320 (arguing that in formal design the WTO dispute settlement system is subject to extensive political controls, but in practice it is far more powerful because of the relinquishment of decision-making by the WTO's political organs to the dispute settlement system). Bartels (n 23) 864-866. Claus-Dieter Ehlermann, "Six Years on the Bench of the "World Trade Court" Some Personal Experiences as Member of the Appellate Body of the World Trade Organization' (2002) 36 JWT 605, 632-636.

64 Under article IX:2 of the WTO Agreement, the Ministerial Conference and the General Council have the exclusive authority to adopt authoritative interpretations of WTO agreements, by a three-fourths majority of members. This power has not been used despite a few attempts, for various reasons, including that the WTO continues to operate by consensus: see eg Claus-Dieter Ehlermann and Lothar Ehring, 'The Authoritative Interpretation Under Article IX:2 of the Agreement Establishing the World Trade Organization: Current Law, Practice and Possible Improvements' (2005) 8 JIEL 803, 813-818. Under article X of the WTO Agreement, the Ministerial Conference (and the General Council in between ministerial conferences) can submit proposed amendments to the WTO agreements to members by a two-thirds majority vote (art X:1). However, in most instances amendments only take affect for a member once it has accepted the amendment, and amendments have not been an effective tool for changing WTO law. See eg Hunter Nottage and Thomas Sebastian, 'Giving Legal Effect to the Results of WTO Trade Negotiations: An Analysis of the Methods of Changing WTO Law' (2006) 9 JIEL 989, 991-994.

65 Gregory Shaffer, 'A Tragedy in the Making? The Decline of Law and the Return of Power in International Trade Relations' (2018) 44 The Yale Journal of International Law Online 37, 42-46; Robert McDougall, 'Revitalizing the WTO: Settling Trade Disputes in a Turbulent Multipolar World' (Bertelsmann Stiftung 2019) $5^{-7}<$ www.bertelsmann-stiftung.de/file admin/files/BSt/Publikationen/GrauePublikationen/MT_Revitalizing_the_WTO.pdf> accessed 2 August 2019 .

66 See eg Ehlermann (n 63) 635-636; Broude (n 1) 335-343.

67 Shaffer (n 65) 45; Pauwelyn, 'Transformation' (n 52) 38-42. But see Broude (n 1) 309-320 (suggesting that the argument regarding loss of a veto is not a full explanation, and 
adjudication. ${ }^{68}$ As we will see below, the reforms that have been proposed during the current crisis involve both elements that would reduce the interpretative power of the $\mathrm{AB}$, and elements aimed at activating political decision-making. ${ }^{6}$

\subsection{Judicial Independence and Accountability}

It is important to unpack the concept of judicial independence because, as other have noted, this is a value that a political body that oversees an international tribunal, such as the DSB, can undermine. ${ }^{70}$ Judicial independence at base refers to a range of institutional features that enable judges to perform their decision-making role, or judicial function, 'unconstrained by the preferences of other actors. ${ }^{71}$ In the domestic setting, judicial independence is seen as primarily about freedom from control by other branches of government, ${ }^{72}$ whereas in the international sphere judicial independence is focused on freedom from control by the States parties to a tribunal. ${ }^{73}$ In practice, judicial independence is relative rather than absolute and is balanced against certain other competing interests. ${ }^{74}$ In the context of international adjudication, those other interests include control by, and responsiveness to the concerns of, member States, which help maintain States' willingness to support international tribunals. ${ }^{75}$

members also maintain the consensus practice because it is politically convenient to relinquish decision-making to adjudicators).

68 Shaffer (n 65) 45; Richard H Steinberg, 'The Impending Dejudicialization of the WTO Dispute Settlement System?' (2018) 112 ASIL Proceedings 316, 320-21.

69 The proposals are analysed below in Part 4.2.2.

$70 \quad$ See supra $\mathrm{n} 6$.

71 Erik Voeten, 'International Judicial Independence' in Jeffrey L Dunoff and Mark A Pollack (eds), Interdisciplinary Perspectives on International Law and International Relations: The State of the Art (CUP 2012) 421, 422; Mahoney (n 6) 322-323 (outlining further relevant authorities); Shany (n 8) 98-99.

72 Voeten (n 71) 422; Mahoney (n 6) 322-23; Frank Cross, 'Judicial Independence' in Gregory A Caldeira, R Daniel Kelemen, and Keith E Whittington (eds), The Oxford Handbook of Law and Politics (OUP 2008) 557, 558.

73 Voeten (n 71) 422; Robert O Keohane, Andrew Moravcsik and Anne-Marie Slaughter, 'Legalized Dispute Resolution: Interstate and Transnational' (2000) 54 Intl Org 457, 459$62,470-72$.

74 Anja Seibert-Fohr, 'International Judicial Ethics' in Cesare PR Romano, Karen J Alter and Yuval Shany (eds), The Oxford Handbook of International Adjudication (OUP 2013) 757, 774; Cross (n 72) 557, 558, 565 ('Judicial independence is not a binary condition but exists on a continuum of relative independence and accountability').

75 See Jacob Katz Cogan, 'Competition and Control in International Adjudication' (2008) 48 Va J Intl L 411, 414-15 (on the tension between independence and control by States in relation to international courts); Shany (n 8) 109-10 (on the tension between judicial independence and responsiveness to mandate providers); Helfer and Slaughter (n 59) 942-3; 
Judicial accountability 'is in many ways the other side of the coin to judicial independence. ${ }^{76}$ Like judicial independence, judicial accountability is multifaceted.It applies to a court or tribunal collectively and to individual members. ${ }^{77}$ Additionally, the actors to whom courts or tribunals are accountable can vary, although for present purposes, given my focus on the DSB, what is relevant is accountability to the States parties to a tribunal when acting through the political institution responsible for governing the tribunal. ${ }^{78}$ Furthermore, there are also different forms of judicial accountability that apply to international courts. ${ }^{79}$ Some of these, although important, are not the focus of this article. For example, financial accountability relates to the manner in which a court or tribunal manages its budget and exists in relation to the political governance body that approves the budget ${ }^{80}$ Individually, judges are also accountable for their conduct pursuant to requirements of impartiality and prohibitions on certain forms of extra-judicial activity, which are enforced through procedures for self-recusal, disqualification or removal of judges. ${ }^{81}$

For obvious reasons, the idea of judicial accountability in relation to the content of judicial decisions is controversial, being in tension with

See also Cosette D Creamer, 'From the WTO's Crown Jewel to Its Crown of Thorns' (2019) 113 AJIL Unbound 51, 54-55 (suggesting that judicial responsiveness need not undermine judicial independence).

76 Mahoney (n 6) 347-348. While judicial independence and accountability are often thought of as being in an inverse relationship, Dunoff and Pollack, in an important analysis that is focused on the accountability of individual judges through procedures around reappointment, show that it is possible to maximise both independence and accountability if judicial transparency, understood as the possibility of identifying a particular judge's position or vote, is minimised: Jeffrey L Dunoff and Mark A Pollack, 'The Judicial Trilemma' (2017) 111 AJIL 225, 234-36, 270-71.

77 Mahoney (n 6) 339; Dunoff and Pollack (n 76 ) 233-34.

78 Others have also suggested that the idea of accountability of judicial organs to member States is a relevant concept in this context: Blokker (n 2) 38-9; Shany (n 8) 109-10; Ronli Sifris, 'Weighing Judicial Independence Against Judicial Accountability: Do the Scales of the International Criminal Court Balance?' (2008) 8 Chi-Kent J Intl \& Comp L 88, 96-7, 108-9. See also Allison Marston Danner, 'Enhancing the Legitimacy and Accountability of Prosecutorial Discretion at the International Criminal Court' (2003) 97 AJIL 510, 522-34 (analysis of the accountability of the ICC prosecutor).

79 Mahoney (n 6) 339. See further Ruth W Grant and Robert O Keohane, 'Accountability and Abuses of Power in World Politics' (2005) 99 APSR 29, 29, 34-7 (typology of accountability mechanisms highlighting that both the standards used to asses conduct within such mechanisms, and the actors who are entitled to call others to account, are multiple).

8 o Blokker (n 2) 39; Mahoney (n 6) 339 .

81 See eg Mahoney (n 6) 340-44; Seibert-Fohr (n 74) 766-771. 
judicialindependence orfreedom in decision-making from outsideinfluences. ${ }^{82}$ Nevertheless, in my view, the idea of accountability in relation to the content of decisions is relevant to understanding the position of WTO adjudicatory bodies, given the political realities within which they operate, where WTO members have certain opportunities, given relevant institutional design features, to pursue such accountability in relation to adjudicators collectively and individually. ${ }^{83}$ For example, the right of members to comment on panel or AB decisions in the DSB is at least a weak form of accountability concerning the content of decisions. Likewise, as Jeffrey Dunoff and Mark Pollack have teased out, given the process for $\mathrm{AB}$ reappointments, individual $\mathrm{AB}$ members seeking reappointment are highly accountable for decisions made in their first term, both to the nominating State and other members who might veto reappointment. ${ }^{84}$ Certain proposals that have been made in the context of the current crisis over AB appointments, which will be analysed in Part 4, would also increase the potential for members to hold WTO adjudicators accountable for the content of their decisions. For example, the idea of introducing an annual meeting between WTO members and the AB, where members could express their views on trends in jurisprudence or systemic issues, in a manner unrelated to the adoption of particular reports, would be a weak form of additional accountability regarding the content of the AB's decisions. ${ }^{85}$

In this context, an interesting question is whether various mechanisms for WTO members to correct law-making contributions of adjudicators should be

82 A useful analysis from a domestic perspective of the concepts of judicial independence and accountability, with substantial discussion of the idea of accountability regarding the content of judicial decisions, is G Allan Tarr, Without Fear or Favor: Judicial Independence and Judicial Accountability in the States (Stanford University Press 2012) 90-121. The idea of accountability regarding the content of judicial decisions in noted but not further discussed in Mahoney (n 6) 339-40.

83 Often the accountability mechanisms I have in mind have been conceptualised as control mechanisms that member States may utilise in relation to an international court, however this is consistent with the idea of judicial accountability since responsiveness to member State concerns is a form of accountability: Shany (n 8) 109-110. Important literature on such control mechanisms includes Helfer and Slaughter (n 66) 945-954; Ginsburg (n 65) 659-667. See also Cogan (n 75) 420-31 (suggesting such control mechanisms are less effective than is often portrayed).

84 Dunoff and Pollack ( $\mathrm{n} 76)$ 235. Theoretically, all WTO members have such a veto power. However, as discussed below, in practice it may be difficult for less powerful members to sustain a veto in the face of pressure from the rest of the membership: below text at $\mathrm{n} 177$.

85 For outline of such proposals see below text at $n$ 160-162. Similarly, proposals that have sometimes been made for an external body, more specialised than the full DSB, to review particular decisions of the $\mathrm{AB}$ would constitute an additional accountability mechanism in relation to the content of decisions: see eg below text at $n$ 163-164. 
seen as a form of judicial accountability, and the extent to which such mechanisms undermine judicial independence. Writing in a domestic setting, Alan Tarr has argued that a decision by the legislature to change the law in response to judicial decisions is not a form of judicial accountability, on the basis that correction through legislation typically only applies to future cases and does not threaten judicial independence. ${ }^{86}$ Similarly, in relation to the WTO, a decision by members to adopt an authoritative interpretation in reaction to a decision of adjudicators is fully consistent with judicial independence, since such a possibility is provided for ex ante, in the Agreement Establishing the WTO, and does not restrict adjudicators' freedom to decide in future cases. ${ }^{87}$ For similar reasons, some of the proposed reforms, discussed in Part 4, designed to reduce the law-making influence of adjudication, such as clarifying that $\mathrm{AB}$ or panel reports only apply to the dispute in which they are adopted, or instructing the $\mathrm{AB}$ to decide issues only to the extent necessary to resolve disputes, would not restrict the independence of future WTO adjudicators. On the other hand, the idea that has sometimes been proposed of permitting the DSB to partially adopt reports, or permitting the disputing parties to remove parts of reports prior to adoption, is a form of judicial accountability (to the DSB or disputing parties) concerning the content of decisions in specific cases. ${ }^{88}$ Likewise, any suggestion that WTO adjudicators should reverse a particular decision simply because it is vigorously criticised by members in the DSB would be a form of accountably (to members) regarding the content of decisions that is difficult to reconcile with a meaningful degree of judicial independence. ${ }^{89}$ Overall, a key part of the distinction between the above situations is the difference between mechanisms that would enable members to correct adjudicators' law-making contributions on a prospective and general basis (that do not necessarily undermine judicial independence), and

86 Tarr (n 82) 94-95. See also Paul Gewirtz, 'Independence and Accountability of Courts' (2005) 1 China Law Review 11, 22-3 (suggesting that legislative reversal of judicial decisions through generally applicable laws is acceptable from the perspective of judicial independence, but legislative reversal of the outcomes of specific cases is not).

87 Similarly, efforts by WTO members to develop subsequent agreements or practice, including in response to particular adjudicatory decisions, seem consistent with the notion of judicial independence.

88 For discussion of proposals regarding partial adoption see below text at n 166-167.

89 Consider however Creamer and Godzimirska's more subtle suggestion that while adjudicators should not necessarily follow members' expressed interpretative preferences, given the importance of judicial independence, they should 'consider these preferences and provide reasoned decisions that in some way speak to these views or interests': Creamer and Godzimirska, 'Deliberative Engagement' (n 1) 449-450, 460-461. 
mechanisms that would enable political control over the outcome in particular disputes (that do undermine adjudicators' independence). ${ }^{90}$

This Part has developed the conceptual side of my argument that the DSB is an important voice mechanism within the WTO, which cultivates member State political buy-in and internal legitimacy, but may also be used by members in ways that undermine judicial independence. The next Part applies the more theoretical ideas developed here to key instances where the DSB has been used as a voice mechanism.

This Part undertakes a detailed analysis of the two most significant episodes in which WTO members have used the DSB as a voice mechanism to criticise the performance of adjudicators: the crisis of a generation ago over the acceptance of unsolicited amicus curiae briefs, and the crisis of the past few years over $\mathrm{AB}$ appointments. Although these are far from the only instances of the DSB being used by members to voice disapproval with adjudicators' decisionmaking, they are the most important examples, involving sustained criticism over numerous meetings. ${ }^{91}$ My focus is on what these episodes indicate about

9o See above $\mathrm{n}$ 86. Others who have analysed the independence of the ICC from the ASP have also emphasised such a distinction, suggesting that the ASP should not have the ability to influence the outcome of ongoing cases: Woolaver and Palmer (n 6) 650-52, 661-63; Raab and Bevers (n 6) 135. The Court of Justice of the European Union emphasised a similar principle in holding that the EU was not permitted to agree to authoritative interpretations of the Comprehensive Economic and Trade Agreement Between Canada and the European Union, when acting through the CETA Joint Committee (a political body established by the treaty), that would affect investor-State disputes that were pending or had already been decided by the tribunals created under the Agreement to hear such disputes. This restriction on the EU's ability to agree to authoritative interpretations followed from the requirement of judicial independence under EU law: see CJEU, Opinion 1/17, EU-Canada CET Agreement, 30 April 2019, ECLI:EU:C:2019:341, paras 189191, 234-237.

91 Other instances of numerous members criticising specific decisions include the following: DSB, Minutes of Meeting Held on 11 February 2000, WT/DSB $/ M / 75^{2} 5^{-9}$, where several members criticised the Compliance Panel's finding in WTO, Australia - Subsidies Provided to Producers and Exporters of Automotive Leather (Article 21.5 - US), Report of the Panel, (21 January 2000) WT/DS126/RW, requiring repayment of prohibited subsidies. DSB, Minutes of Meeting Held on 22 and 23 September 1999, WT/DSB/M/68, 14-23, where numerous members criticised the AB's approach to various issues in WTO, India - Quantitative Restrictions on Imports of Agricultural, Textile and Industrial Products, Report of the Appellate Body, (23 August 1999) WT/DS9o/AB/R. See also Godzimirska (n 1) 136-38. Terrence P Stewart, 'Can the WTO Be Saved from Itself? Not Without a Major 
how political bodies that oversee international tribunals can operate as voice mechanisms, which enable member States to communicate dissatisfaction to adjudicators, but can also undermine judicial independence.

\subsection{The DSB as Voice Mechanism I: the Amicus Curiae Saga}

A formative instance of the DSB operating as a voice mechanism was the sustained criticism, over several years, that numerous WTO members expressed in relation to the AB's decisions regarding the power to accept unsolicited amicus curiae briefs. This issue was initially taken up in the DSB in its meeting of 6 November 1998, where the AB and Panel reports in United States Shrimp came up for adoption. The Panel had received two unsolicited amicus briefs from environmental non-governmental organizations (NGOs), and held that ' $[\mathrm{a}] \mathrm{ccepting}$ non-requested information from non-governmental sources would be ... incompatible with provisions of the DSU', although the relevant submissions could be put forward by the parties in their submissions. ${ }^{92}$ The $\mathrm{AB}$ reversed the Panel on this question, holding that panels have 'discretionary authority either to accept and consider or to reject' unsolicited information from non-governmental sources, subject to not "unduly delaying the panel process". ${ }^{93}$ Read in light of the later DSB debates on this issue, the criticism registered in the November 1998 DSB meeting was fairly restrained. A range of predominantly developing WTO members communicated their disapproval of the AB's findings, suggesting, inter alia, that the DSU did not give NGOs the right to submit unsolicited amicus briefs and that the decision had encroached on the right of WTO members to determine the scope of NGO participation. ${ }^{94}$

The next key development in this saga occurred in reaction to the AB Report in United States - Lead and Bismuth, where the AB held that it had the authority to 'accept and consider amicus curiae briefs in an appeal in which we find it pertinent and useful to do so', based on its general power to adopt procedural rules, subject to not contradicting the DSU. ${ }^{95}$ This was a bolder finding than the earlier decision in relation to panels' fact-finding powers because the AB's

Crisis, and Probably Not Even Then' (Paper presented to Washington International Trade Association, 13 April 2018, on file with author) attachments 1 and 2 (documenting numerous statements of member discontent expressed in the DSB).

WTO, United States - Import Prohibition of Certain Shrimp and Shrimp Products, Report of the Panel (15 May 1998) WT/DS58/R, para 7.8. The United States put forward part of one of the amicus briefs in its submissions to the Panel.

WTO, United States - Import Prohibition of Certain Shrimp and Shrimp Products, Report of the Appellate Body (12 October 1998) WT/DS58/AB/R, paras 107-108, 110.

94 DSB, Minutes of Meeting Held on 6 November 1998, WT/DSB/M/50, 2-18.

95 WTO, United States - Imposition of Countervailing Duties on Certain Hot-Rolled Lead and Bismuth Carbon Steel Products Originating in the United Kingdom, Report of the Appellate 
jurisdiction is limited to questions of law. ${ }^{96}$ At the subsequent DSB meeting in June 2000, a somewhat broader group of WTO members expressed dissatisfaction with the AB's decision. Many members suggested that the AB had exceeded its legal authority under the DSU, ${ }^{97}$ and a number expressed surprise that the $\mathrm{AB}$ had not taken into account their prior criticism in relation to how this issue was decided in US - Shrimp. ${ }^{98}$

The key escalation in the amicus saga came in November 2000, when the AB adopted a procedure during the $E C$ - Asbestos appellate proceedings to deal with the anticipated amicus curiae submissions from NGOs. ${ }^{99}$ This led to the calling of a special meeting of the WTO General Council, given the breadth of member disapproval of the AB's decision. ${ }^{100}$ Prior to the General Council meeting occurring the $\mathrm{AB}$ had already decided not to grant leave to any of the applications to file amicus briefs, 11 of which had been received within the deadline set. ${ }^{101}$ The record of the General Council meeting of 22 November 2000 is nevertheless a striking example of the voice mechanism at work, because of the very wide range of WTO members who criticised the procedure adopted by the $\mathrm{AB}$ and their collective intention to send a message to the $\mathrm{AB} \cdot{ }^{102}$ For example, the representative of New Zealand noted the 'importance of familiarizing the Appellate Body with the climate of opinion among Members on such matters. Therefore this discussion had to be seen as providing important feedback'.103 Jamaica 'believed that the message, which was being sent to it [the $\mathrm{AB}$ ] on this issue, was important and quite clear and if heeded, the organization as a whole would emerge healthier.' ${ }^{104}$ Hong Kong noted that ' $[\mathrm{t}]$ he issue before the General Council was systemic and probably constitutional', and 'strongly believed that Members should send the strongest signal to the Appellate

Body (10 May 2000) WT/DS138/AB/R, paras 39, 42. The AB chose not to take the two amicus briefs in question, filed by business groups, into account: para 42.

96 DSU art 17.6.

97 See eg DSB, Minutes of Meeting Held on 7 June 2000, WT/DSB/M/83, paras 12, 14, 15 .

98 ibid paras 13, 23, 27.

99 WTO, European Communities - Measures Affecting Asbestos and Asbestos-Containing Products, Report of the Appellate Body, (12 March 2001) WT/DS135/AB/R, paras 50-52. The background was that at the panel stage in this case, the Panel had received five amicus submissions, two of which it accepted: ibid para 50.

100 Charnovitz (n1) 235. WTO General Council, Minutes of Meeting Held on 22 November 2000, WT/GC/M/6o, paras 1, 11 .

101 Charnovitz (n 1) 235; EC - Asbestos, Report of the Appellate Body (n 99) paras 55-56.

102 See generally WTO General Council, Minutes of Meeting 22 November 2000 (n 100) paras 4-130. The United States was the only delegation to speak in support of the AB's interpretation; its statement appears at paras $74-77$.

103 ibid para 86.

104 ibid para 92. 
Body'. ${ }^{105}$ Singapore, speaking on behalf of the Association of Southeast Asian Nations members, suggested that '[s]ince this procedure was contrary to the prevailing sentiment of the majority of Members, the Appellate Body should withdraw it'.106 Several members suggested that the General Council should have adopted an authoritative interpretation reversing the AB's decision. ${ }^{107}$

Ultimately, the General Council meeting did not result in an authoritative interpretation, given a lack of consensus, but with an undertaking by the Chairman of the DSB to communicate the key points raised in the meeting to the $\mathrm{AB} .{ }^{108}$ These points included the striking statement that, in the Chairman's words, 'the Appellate Body should exercise extreme caution in future cases until Members had considered what rules were needed' regarding amicus participation. ${ }^{109}$ The Chairman predicted that on the basis of this communication 'the Appellate Body would draw its conclusions.'110

A fourth key development in this saga occurred soon afterwards, in the EC-Sardines appeal, where the AB permitted Morocco, a WTO member that had not reserved its third party rights, to submit an amicus curiae brief. ${ }^{111}$ In the subsequent DSB meeting, a wide range of WTO members expressed dissatisfaction with this decision. ${ }^{12}$ Several members suggested that the AB should have taken notice of the prior disapproval expressed by many members in the November 2000 General Council meeting, ${ }^{113}$ or refrained from permitting amicus submissions while members were debating how to regulate the issue. ${ }^{114}$ India suggested 'that the Appellate Body had accepted the amicus brief for the sake of asserting its so-called legal authority to accept such briefs', and '[t]his unfortunate episode would not have occurred had the Appellate Body paid heed to the views expressed by Members' in earlier meetings. ${ }^{115}$ It is notable that across the repeated debates on amicus curiae submissions just outlined,

\footnotetext{
105 ibid paras 22, 28.

106 ibid para 60.

107 ibid paras 122, 109 .

108 ibid paras 131, 113-120.

109 ibid para 120.

110 ibid para 123.

111 WTO, European Communities - Trade Descriptions of Sardines, Report of the Appellate Body (26 September 2002) WT/DS231/AB/R, paras 161-167. The AB did not draw on the brief in its reasoning: see paras 169-170, 314 .

112 DSB, Minutes of Meeting Held on 23 October 2002, WT/DSB/M/134, paras 37-76.

113 ibid paras 61, 69.

114 ibid paras 37,47 .

115 ibid para 61.
} 
numerous WTO members, and the chairperson of the DSB, characterised their statements as serving the purpose of sending a message to the AB. ${ }^{116}$

What conclusions should be drawn about the long-term implications of the repeated exercise of voice by members in relation to the amicus issue? Despite the significant member criticism it faced on this issue in its early years, the $A B$ never backed down from its decision regarding its own and panels' authority to accept unsolicited amicus briefs. ${ }^{117}$ Thus, at one level, this episode was an important sign of the $\mathrm{AB}$ establishing its independence and authority, against the backdrop of an inability of members to reach consensus on an authoritative interpretation. ${ }^{118}$ Yet, as others have highlighted, since the above debates, both panels and the $\mathrm{AB}$ have generally only considered amicus briefs where they are appended by a party to their submissions, or incorporated into the party's submissions. ${ }^{119}$ In a recent empirical analysis covering all WTO disputes until the end of 2014, Theresa Squatrito finds that of the almost 100 amicus submissions to panels or the $\mathrm{AB}, 81.5 \%$ were not considered, and of the minority that were considered, whether the submission was endorsed by a party is the key explanatory factor. ${ }^{120}$ In the years immediately following the above member responses, a few panels even refused to accept unsolicited amicus briefs 'in light of the absence of consensus among WTO Members on' this issue, except if the submission was endorsed by a party. ${ }^{121}$ This record, since the member backlash, has often been interpreted as evidence of the informal but

116 Similarly, in their interviews with WTO delegations, Creamer and Godzimirska found that 'Almost all representatives independently employed the language of "sending messages" to the AB or Secretariat': Creamer and Godzimirska, 'Deliberative Engagement' (n 1) 447 .

117 Robert Howse, 'The World Trade Organization 20 Years On: Global Governance by Judiciary' (2016) 27 EJIL 9, 42-43.

118 ibid 43; Broude (n 1) 201-202.

119 Jeffrey L Dunoff, 'Constitutional Conceits: The WTO's "Constitution" and the Discipline of International Law' (2006) 17 EJIL 647, 660; Theresa Squatrito, 'Amicus Curiae Briefs in the WTO DSM: Good or Bad News for Non-State Actor Involvement?' (2018) 17 WTR 65, $80-81$.

120 Squatrito (n 119) 72, 79-81.

121 WTO, United States - Investigation of the International Trade Commission in Softwood Lumber from Canada, Report of the Panel, (22 March 2004) WT/DS277/R, para 7.10 fn 75; WTO, United States - Final Countervailing Duty Determination with Respect to Certain Softwood Lumber from Canada, Report of the Panel (29 August 2003) WT/DS257/R/Corr.1, para $7.1 \mathrm{fn}$ 75; But see WTO United States - Final Countervailing Duty Determination with Respect to Certain Softwood Lumber from Canada, Report of the Appellate Body (19 January 2004) WT/DS257/AB/R, para 9 (AB 'did not find it necessary to take the two amicus curiae briefs into account in rendering its decision' but did not impose condition that it would only consider the briefs when endorsed by a party); WTO United States Preliminary Determinations with Respect to Certain Softwood Lumber from Canada, Report 
significant political constraints to which WTO adjudicators are subject. ${ }^{122}$ However, several other factors also explain why amicus briefs are often not considered by WTO adjudicators, including that such briefs may not be relevant to the issues under consideration, ${ }^{123}$ and that amicus briefs submitted late in the proceedings may be rejected for due process reasons. ${ }^{124}$

Nevertheless, the member backlash over the amicus issue was a crucial instance of the DSB operating as a voice mechanism that channels member discontent back to the $\mathrm{AB}$ and highlights the boundaries of its strategic space. ${ }^{125}$ Those who were high level insiders within the WTO Secretariat at the time note that the episode 'had a chilling effect on the Appellate Body and panels for some time'126 and 'left the Appellate Body damaged'.127 The amicus episode demonstrated starkly how the DSB's voice function could threaten the AB's judicial independence, with numerous members taking the position that the $\mathrm{AB}$ should have refrained from accepting amicus briefs given the widespread disapproval communicated by the WTO membership. ${ }^{128}$ As Steve Charnovitz notes, the episode suggests that blockage in the legislative processes of the WTO may lead to greater 'extra-legal pressure' being placed on WTO adjudicators. ${ }^{129}$ Finally, and perhaps most importantly, the amicus saga provided strong support for a narrative, advanced by some WTO members and commentators, that the $\mathrm{AB}$ was taking an overly activist approach to filling gaps in the WTO agreements. ${ }^{130}$ As we will see, that claim lies at the heart of the current crisis over $\mathrm{AB}$ appointments.

of the Panel (27 September 2002) WT/DS236/R, para 7.2 (panel accepted one unsolicited amicus brief).

122 Squatrito (n 119) 86 ('political backlash has some sustaining power to constrain in the longrun ... the institutional memory of the early response of states to amicus briefs is long'); Pauwelyn, 'Transformation' (n 52) 49; Dunoff (n 119) 66o; Gregory Shaffer, Manfred Elsig and Sergio Puig, 'The Law and Politics of WTO Dispute Settlement' in Wayne Sandholtz and Christopher A Whytock (eds), Handbook on the Politics of International Law (Edward Elgar 2017) 269, 281, 297.

123 See Malacrida and Marceau (n 12 ) 31.

124 Squatrito (n 119) 81-82.

125 Steinberg (n 54) 266.

126 Steger (n 23) 462.

127 Kuijper (n 14) 125 .

128 Charnovitz (n 1) 236-239 (also highlighting that the General Council meeting in relation to the Asbestos dispute was problematic because members were interfering in an ongoing proceeding).

129 ibid 239. A similar point is made in Thomas Cottier, 'The WTO Dispute Settlement System: New Horizons' (1998) 92 ASIL Proceedings 86, 90.

130 Bartels (n 23) 861-862; Steinberg (n 54) 251. 


\section{2 \\ The DSB as Voice Mechanism II: Veto by the United States (2016-Present)}

Alongside the amicus saga, the other key example of the DSB operating as a voice mechanism in the WTO's history is the ongoing crisis over AB appointments. This has involved the United States blocking the (re)appointment of $\mathrm{AB}$ members and using DSB meetings to communicate lengthy criticisms of various aspects of the AB's functioning. The result of the US blocking, as is well known, is that currently only three out of seven $A B$ positions are filled the minimum number required to enable the $\mathrm{AB}$ to operate. ${ }^{131}$ Unless further appointments are made, which appears unlikely, the $\mathrm{AB}$ will cease to be able to operate after 10 December 2019, when the terms of two more members expire. If that occurs, the WTO will partly revert to the situation that prevailed in the GATT, as a losing party would be able to block the adoption of a panel report. Specifically, the losing party could lodge an appeal, despite the absence of a functioning $\mathrm{AB}$ to hear it, and under the DSU, a panel report cannot be adopted while an appeal is pending. ${ }^{132}$ Much has already been written about the current crisis. ${ }^{133}$ In the following, my focus is on what this episode tells

$131 \quad$ DSU art 17.1.

132 DSU art 16.4; Shaffer (n 65) 48 (highlighting such a situation would be different from GATT dispute settlement since the establishment of a panel could not be blocked). Note that for panel reports appealed before or on 10 December 2019, the AB would be able to complete pending appeals by applying Rule 15 of its Working Procedures, which is outlined below text at $\mathrm{n}$ 144. Furthermore, for members able to agree among themselves, there are options to avoid panel reports being appealed 'into the void' after 10 December 2019, including agreeing to arbitration under Article 25 of the DSU for determining appeals, or agreeing that panel reports will not be appealed. For analysis of such options see eg Joost Pauwelyn, 'WTO Dispute Settlement Post 2019: What to Expect?' (2019) 22 JIEL 297. See also 'Interim Appeal Arbitration Pursuant to Article 25 of the DSU' (25 July 2019) JOB/ DSB/1/Add.11, whereby Canada and the EU, for disputes between themselves, indicate their intention to enter into interim arbitration agreements, under Article 25.2 of the DSU, to enable appeals from panel reports to be determined if the Appellate Body has an insufficient number of members.

133 See eg 'Symposium: International Trade in the Trump Era' (2018) 44 The Yale Journal of International Law Online 1-103; 'Symposium: Can International Trade Law Recover?' (2019) 113 AJIL Unbound 38-66; Robert McDougall, 'The Crisis in WTO Dispute Settlement: Fixing Birth Defects to Restore Balance' (2018) 52 JWT 867; Pieter Jan Kuijper, 'The US Attack on the WTO Appellate Body' (2018) 45 LIEI 1; Jennifer Hillman, 'Three Approaches to Fixing the World Trade Organization's Appellate Body: The Good, the Bad and the Ugly?' (IIEL Issues Brief 2018) <https://georgetown.app.box.com/s/966hfvosmran4m31bi blgfszj42za4ob > accessed 12 September 2019; Tetyana Payosova, Gary Clyde Hufbauer, and Jeffrey J Schott 'The Dispute Settlement Crisis in the World Trade Organization: Causes and Cures' (Peterson Institute Policy Brief 18-5, March 2018) <https://piie.com/system/ files/documents/pb18-5.pdf $>$ accessed 12 September 2019; Ernst-Ulrich Petersmann 'How Should WTO Members React to Their WTO Crises?' (2019) 18 WTR 503; Giorgio Sacerdoti, "The WTO Dispute Settlement System and the Challenges to Multilateralism: 
us about the DSB as a voice mechanism, and the tension between maintaining member State political support and safeguarding judicial independence. My analysis of the numerous reform proposals made in response to the current crisis provides an assessment of how these would affect the wider balance between adjudicatory and political power within the WTO, as the DSB is one aspect of that balance, which is affected by the interaction of numerous different design features.

\section{2 .1}

Recapping the Current Crisis: Complaints of the United States and Reform Proposals

While the United States has expressed dissatisfaction with aspects of the AB's adjudicative approach for most of its existence, ${ }^{134}$ the current crisis erupted on 11 May 2016, when the United States informed the Chairman of the DSB that it would not support the reappointment of Seung Wha Chang, a sitting AB member. ${ }^{135}$ As noted above, the (re)appointment of $\mathrm{AB}$ members is subject to the DSB's default rule of consensus, meaning it can be blocked by a member who is present and objects. ${ }^{136}$ In explaining its position in the DSB, the United States highlighted three reports in which Chang had been involved, that, in the view of the United States, exceeded the role of the AB. Specifically, the United

Consolidating a "Common Global Good" in Denise Prévost, Iveta Alexovičová and Jens Hillebrand Pohl (eds), Restoring Trust in Trade: Liber Amicorum in Honour of Peter Van Den Bossche (Hart 2018) 87; Bernard M Hoekman and Petros C Mavroidis, 'Burning Down the House? The Appellate Body in the Centre of the WTO Crisis' (EUI Working Paper RSCAS 2019/56) <https://cadmus.eui.eu/handle/1814/63666> accessed 12 September 2019; What Kind of Dispute Settlement for the World Trade Organization? (World Trade Institute 2019) <www.wti.org/media/filer_public/77/04/7704206f-6db2-4ef8-a7a8-e4c1066ad93a/ sessions_123_wto_ds_e-book.pdf> accessed 12 September 2019.

134 See eg Stewart (n 91) attachments 1 and 2.

135 DSB, Minutes of Meeting Held on 23 May 2016, WT/DSB/M/379, para 6.1. The US veto with respect to Chang was unprecedented because Chang was a sitting $\mathrm{AB}$ member and was not a US national. The United States has always had a national on the $\mathrm{AB}$, and has previously blocked its own nationals from being reappointed where it disapproved of their approach in their first term. Likewise, the United States has prevented the appointment of non-US nationals who were nominated by other WTO members. For important analyses of the $\mathrm{AB}$ appointments process that discuss these prior instances see Manfred Elsig and Mark A Pollack, 'Agents, Trustees, and International Courts: The Politics of Judicial Appointment at The World Trade Organization' (2014) 20 EJIR 391, 406-409; Dunoff and Pollack (n 76) 267-270.

136 DSU Arts 2.4 and 17.2. Arguably, the appointment of AB members could be placed on the agenda of the WTO General Council, which can act through majority voting (under Article IX:1 of the WTO Agreement): see Kuijper (n 133) 10; Henry Gao, 'Disruptive Construction or Constructive Destruction? Reflections on the Appellate Body Crisis' in Chang-fa Lo, Junji Nakagawa and Tsai-fang Chen (eds), The Appellate Body of the WTO and Its Reform (Springer 2020) 215, 234-35. 
States criticised the presence of extensive obiter dicta statements, and questioning during oral hearings by Chang that focused on issues not in dispute. ${ }^{137}$ While many other members criticised the approach of the United States, given its implications for the independence of the $A B,{ }^{138}$ the United States did not change its position, and by the DSB meeting of 21 July 2016 agreement was reached to launch an appointment process to fill the vacancy left by the failure to reappoint Chang. ${ }^{139}$ Ultimately, the initial 2016 phase of the current crisis was resolved at the DSB meeting of 23 November 2016, where two new members of the $A B$ were appointed, respectively to fill the vacancies left by the failure to reappoint Chang and the departure of the Chinese $\mathrm{AB}$ member whose second term had expired in May 2016.

By the beginning of 2017, the DSB faced filling the vacancies arising from the departure of two second-term AB members, Ricardo Ramírez-Hernández, whose term expired on 30 June 2017, and Peter Van den Bossche, whose term expired on 11 December 2017. Between February-July 2017 this issue was on the DSB's agenda at each regular meeting, but the selection processes for these vacancies were not opened, partly due to a procedural disagreement between the European Union (EU) and Latin American group. ${ }^{140}$ Beginning in August 2017, the United States dramatically escalated its exercise of voice by blocking all attempts to launch a process to (re)appoint $\mathrm{AB}$ members, resulting in an increasing number of vacant seats. ${ }^{141}$

Consistently with Hirschman's concept of voice, the United States, while blocking all $\mathrm{AB}$ (re)appointments, has used DSB meetings to communicate a range of criticisms of the AB's performance, which have effectively been

137 DSB, Minutes 23 May 2016 (n 135) paras 6.3-6.9.

${ }_{13} 8$ ibid paras 6.12, 6.14, 6.18, 6.21, 6.23, 6.25, 6.29, 6.44, 6.46; DSB, Minutes of Meeting Held on 22 June 2016, WT/DSB/M/38, paras 11.11, 11.27. All living former AB members also wrote to the Chairman of the DSB expressing their concern on this basis. Separately, the current $\mathrm{AB}$ members also wrote to the Chairman to express concern. These communications are available in 'Appellate Body Annual Report for 2016' (16 May 2017) WT/AB/27, 102-5.

139 DSB, Minutes of Meeting Held on 21 July 2016, WT/DSB/M/383, paras 11.1-11.3.

140 The disagreement concerned whether to launch one process to fill both vacancies or two independent processes: See eg DSB, Minutes of Meeting Held on 22 May 2017, WT/ $\mathrm{DSB} / \mathrm{M} / 397$, paras 10.2, 11.3. In retrospect, there was a missed opportunity at the DSB meetings of May, June, and July 2017, where the United States expressed its willingness to launch a first selection process, to fill the vacancy left by Ramírez-Hernández, and the issue did not proceed due to the EU's position that the selection process for the second coming vacancy had to be launched at the same time: para 10.3.

141 An unexpected development that facilitated the efforts of the United States was that the $\mathrm{AB}$ member who filled the vacancy arising from Chang's seat in 2016, Hyun Chong Kim, resigned on 1 August 2017 with immediate effect. As well as Ramírez-Hernández and Van den Bossche's terms expiring without replacements being appointed, in August 2018 the United States blocked the reappointment of Shree Baboo Chekitan Servansing. 
set out as demands that must be met before the United States will remove its block. ${ }^{142}$ The complaints/demands of the United States can be summarised as follows: ${ }^{143}$

1. That $\mathrm{AB}$ members whose terms expire during the determination of an appeal cannot be authorised by the $\mathrm{AB}$ to complete the appeal, as provided for in Rule 15 of the AB's working procedures, and the DSB must authorise former members to continue to serve on pending appeals, given that under the DSU, the DSB has the power to (re)appoint members. ${ }^{144}$

2. That the $A B$ has not observed the 9o-day limit for appellate proceedings under the DSU. Relatedly, that unless the $\mathrm{AB}$ receives the prior agreement of the disputing parties to exceed the 9o-day time limit, reports circulated outside that time limit cannot be adopted pursuant to the reverse consensus procedure. ${ }^{145}$

142 See eg 'Statements by the United States at the WTO General Council Meeting' (15 October 2019) <https://geneva.usmission.gov/2019/10/15/statements-by-the-unitedstates-at-the-wto-general-council-meeting/> accessed 16 October 2019. In March 2019, the US Trade Representative, Robert Lighthizer, stated: 'If you're not willing to be bold and use the only leverage you have with the WTO, which is to say that we won't approve the appointment of Appellate Body members without reform, I don't know any other way to do it': Hannah Monicken and Brett Fortnam, 'Lighthizer: Appellate Body Blocks the Only Way to Ensure Reforms' Inside US Trade Daily Report (13 March 2019).

143 A consolidated version of the concerns of the United States is presented in United States Trade Representative, 'The President's 2018 Trade Policy Agenda', $22-28<$ https://ustr.gov/ sites/default/files/files/Press/Reports/2018/AR/2018\%20Annual\%2oReport\%2oI.pdf> accessed 2 August 2019.

144 See eg DSB, Minutes of Meeting Held on 31 August 2017, WT/DSB/M/400, paras 5.45.5; DSB Minutes of Minutes of Meeting Held on 28 February 2018, WT/DSB/M/409, paras 7.4-7.8; WTO AB, 'Working Procedures for Appellate Review', WT/AB/WP/6 (16 August 2010), $\mathrm{r}$ 15. The working procedures are adopted by the AB pursuant to DSU art 17.9. Each time an $\mathrm{AB}$ report has come up for adoption that was signed by a former member who continued to serve pursuant to an authorisation from the AB under Rule 15, the United States has contended that the report was not a report provided to the DSB by three $\mathrm{AB}$ members, and thus could not benefit from the normal reverse consensus rule for adoption, and had to be adopted by consensus: see eg DSB, Minutes of Meeting Held on 29 September 2017, WT/DSB/M/402, para 5.11; DSB, Minutes of Meeting Held on 22 November 2017, WT/DSB/M/404, paras 5.6-5.7.

145 DSB, Minutes of Meeting Held on 22 June 2018, WT/DSB/M/414, paras 5.2-5.22. The $\mathrm{AB}$ has previously at times been unable to issue reports within the 9o-day time limit under DSU art 17.5. There is disagreement among WTO members about the appropriate approach to this issue. The United States and some other members have expressed the view that prior to 2011 the $\mathrm{AB}$ had always sought the agreement of the disputing parties, and the $\mathrm{AB}$ should seek the agreement of the parties to permit the report to be deemed to be circulated consistently with art 17.5. Although other members have registered this view when reports issued outside the 9o-day time limit have been adopted, none appears 
3. That the $A B$ has engaged in appellate review of panels' findings of fact and panels' findings regarding the content of members' municipal law, which is contrary to the limitation of appeals to issues of law in DSU article 17.6. ${ }^{146}$

4. That certain findings of the $A B$ have not been necessary to resolve the relevant dispute and thus amounted to 'advisory opinions.' ${ }^{147}$ Relatedly, the United States claims that a range of $\mathrm{AB}$ interpretations have added to or diminished members' rights under the WTO agreements. ${ }^{148}$

5. That the $\mathrm{AB}$ has introduced a doctrine of binding precedent, whereas there is only a legal basis for prior reports being persuasive for subsequent panels. ${ }^{149}$

While several of these concerns are shared by other WTO members, the arguments of the United States are far from uncontested. ${ }^{150}$ Nevertheless, the demands of the United States have shaped, to varying degrees, all of the reform proposals that have been put forward since mid-2018 by a wide range of WTO members, in some 12 different iterations. ${ }^{151}$ This correspondence is significant

to have taken a definitive position that the relevant report cannot benefit from the reverse consensus rule (as the United States now suggests): see eg DSB, Minutes of Meeting Held on 5 October 2011, WT/DSB/M/304, paras 13, 15-19; DSB, Minutes of Meeting Held on 23 July 2012, WT/DSB/M/320, paras 97-98, 103. In contrast, certain WTO members have expressed the view that the $\mathrm{AB}$ does not need to obtain the parties' consent in order to exceed the 9o-day time limit: see eg DSB, Minutes of Meeting Held on 19 June 2015, WT/ DSB/M/364, paras 7.14-7.15; DSB, Minutes of Meeting 23 July 2012, paras 101, 106, 108.

146 See eg DSB, Minutes of Meeting Held on 27 August 2018, WT/DSB/M/417, paras 4.2-4.17; DSB, Minutes of Meeting Held on 26 September 2018, WT/DSB/M/419, paras 4.7-4.11.

147 See eg DSB, Minutes of Meeting Held on 29 October 2018, WT/DSB/M/420, paras 4.2-4.19.

148 USTR, 2018 Trade Policy Agenda (n 143) 22-23.

149 See eg DSB, Minutes of Meeting Held on 18 December 2018, WT/DSB/M/423, paras $4.2-4.25$.

150 For scholarly responses see eg Gao (n 136); Petersmann (n 133); Hoekman and Mavroidis (n 133) 12-13.

151 'Communication from the European Union, China, Canada, India, Norway, New Zealand, Switzerland, Australia, Republic of Korea, Iceland, Singapore, Mexico, Costa Rica and Montenegro to The General Council' (11 December 2018) WT/GC/W/752/ Rev.2; Communication from the European Union, China, India and Montenegro to the General Council' (11 December 2018) WT/GC/W/753/Rev.1. 'Adjudicative Bodies: Adding to or Diminishing Rights or Obligations under the WTO Agreement. Communication from Australia, Singapore, Costa Rica, Canada and Switzerland to the General Council' (11 December 2018) WT/GC/W/754/Rev.2. 'Fostering a Discussion on the Functioning of the Appellate Body Communication from Honduras' (21 January 2019) WT/GC/W/758. 'Fostering a Discussion on the Functioning of the Appellate Body Communication from Honduras' (21 January 2019) WT/GC/W/759. 'Fostering a Discussion on the Functioning of the Appellate Body: Addressing the Issue of Alleged Judicial Activism by the Appellate Body. Communication from Honduras' (29 January 2019) WT/GC/W/76o. 
because it suggests that the aggressive exercise of voice by the United States has been effective in establishing certain pre-conditions for the continued existence of the AB. ${ }^{152}$ While none of these reform proposals have received consensus support to date, ${ }^{153}$ many of them are noteworthy for the purposes of this article, because they would alter the relationship between political and adjudicative processes within the WTO.

A number of the proposals, endorsed by a diverse range of WTO members, would scale back the requirement that the $\mathrm{AB}$ 'shall address each of the issues raised' in an appeal, ${ }^{154}$ for example by providing that it shall only address such issues 'to the extent necessary for the resolution of the dispute.'.155 This would

'Fostering a Discussion on the Functioning of the Appellate Body: Addressing the Issue of Precedent. Communication from Honduras' (4 February 2019) WT/GC/W/761. 'Guideline Development Discussion: Communication from the Separate Customs Territory of Taiwan, Penghu, Kinmen and Matsu to the General Council' (13 February 2019) WT/GC/W/763. 'Guidelines for the Work of Panels and the Appellate Body - Communication from Brazil, Paraguay and Uruguay' (25 April 2019) WT/GC/W/767/Rev.1. 'General Council - Informal Process on Matters Related to the Functioning of the Appellate Body - Communication from Japan, Australia and Chile' (26 April 2019) WT/GC/W/768/Rev.1. 'General Council Decision on the Dispute Settlement System of WTO - Communication from Thailand' (26 April 2019) WT/GC/W/769. 'Appellate Body Impasse - Communication from the African Group' (26 June 2019) WT/GC/W/776. For a summary of the discussions that have occurred among WTO members on the basis of these proposals, including a draft General Council decision that was not adopted, see 'Informal Process on Matters Related to the Functioning of the Appellate Body - Report by the Facilitator, H.E. Dr David Walker (New Zealand)' (15 October 2019) JOB/GC/222. See also the previous Report by the Facilitator (25 July 2019) JOB/GC/220. Note that the form of the proposals differ. While some of the proposals are for amendments to the DSU, which would require consensus under art X:8 of the WTO Agreement, others are advanced as decisions of the General Council or the DSB, endorsing 'guidelines' for the AB. Decisions of the General Council can clearly be taken by majority voting (under art IX:1 of the WTO Agreement). The position is less certain for decisions of the DSB, because art 2.4 of the DSU states that 'where the rules and procedures of this Understanding provide for the DSB to take a decision, it shall do so by consensus'. For discussion of reconciling these provisions see Gao (n 136) 234-35.

$15^{2}$ As one former AB member put it ' $[a]$ ny solution that is worked out is going to have to demonstrate that the rest of the world is hearing what the US is saying - even if they don't always agree with the US' claims': Hillman (n 133) 4.

153 See eg 'Statements by the United States at the WTO General Council Meeting' (15 October 2019) (n 142).

154 DSU art 17.12.

155 Communication from the European Union, China, Canada, India, Norway, New Zealand, Switzerland, Australia, Republic of Korea, Iceland, Singapore, Mexico, Costa Rica And Montenegro, WT/GC/W/752/Rev.2 (n 151) Annex para 4. See also Report by the Facilitator, $\mathrm{JOB} / \mathrm{GC} / 222$ (n 151) Annex (AB 'shall address issues raised by parties ... only to the extent necessary to assist the DSB in making the recommendations or in giving the ruling provided for in the covered agreements in order to resolve the dispute'). Communication from 
obviously reduce the $A B$ 's interpretative influence and directly responds to the charges of the United States concerning 'advisory opinions' and the AB adding to or diminishing the rights of members. Similarly, many of the proposals directly respond to the argument of the United States that the $\mathrm{AB}$ has overreached in reviewing panels' fact-finding, and specifically findings regarding the meaning of domestic law, by including clarifications to the effect that the $\mathrm{AB}$ 'shall not review panel's fact-finding, such as meaning of municipal law, as an issue of law'.156 Additionally, several of the proposals respond to the concerns of the United States (and also some other members) regarding the $\mathrm{AB}$ exceeding the 9o-day time-limit for appeals without permission, for example by providing that the $\mathrm{AB}$ can only do so with the agreement of the parties. ${ }^{157}$ On the issue of former $\mathrm{AB}$ members hearing appeals, while some members have endorsed the position of the United States that this can only occur with the DSB's authorisation, ${ }^{158}$ other reform proposals would enable former members to complete appeals in certain circumstances, for example where an oral hearing had taken place during the member's term..$^{159}$

Brazil, Paraguay and Uruguay, WT/GC/W/767/Rev.1 (n 151) paras 5.1-5.3. Communication from Thailand, WT/GC/W/769 (n 151) paras 13-15. Communication from Honduras, WT/ GC/W/76o (n 151) paras 2.1-2.2.

156 Communication from Japan, Australia and Chile, WT/GC/W/768/Rev.1 (n 151) para 2.2. See also Report by the Facilitator, JOB/GC/222 (n 151) Annex. Communication from the European Union, China, Canada, India, Norway, New Zealand, Switzerland, Australia, Republic of Korea, Iceland, Singapore, Mexico, Costa Rica And Montenegro, WT/ GC/W/752/Rev.2 (n 151) Annex para 3. Communication from Brazil, Paraguay and Uruguay, WT/GC/W/767/Rev.1 (n 151) para 4.1. Communication from Thailand, WT/ GC/W/769 (n 151) paras 11-12. Communication from Honduras, WT/GC/W/76o (n 151) para 2.3 (outlining various options regarding potential clarification of the standard of review on appeal).

157 Communication from the European Union, China, Canada, India, Norway, New Zealand, Switzerland, Australia, Republic of Korea, Iceland, Singapore, Mexico, Costa Rica And Montenegro, WT/GC/W/752/Rev.2 (n 151) Annex para 2. This proposal was not entirely responsive to the criticism of the United States because it made clear that such 'changes do not affect the existing rules on the validity or the adoption of late reports'. See also Report by the Facilitator, JOB/GC/222 (n 151) Annex. Communication from Brazil, Paraguay and Uruguay, WT/GC/W/767/Rev.1 (n 151) paras 3.1-3.2. Communication from Thailand, WT/GC/W/769 (n 151) paras 7-9. Communication from the African Group, WT/GC/W/776 (n 151) para 5.1. Communication from Honduras, WT/GC/W/758 (n 151).

$15^{8}$ Communication from Brazil, Paraguay and Uruguay, WT/GC/W/767/Rev.1 (n 151) para 2.1.

159 Communication from the European Union, China, Canada, India, Norway, New Zealand, Switzerland, Australia, Republic of Korea, Iceland, Singapore, Mexico, Costa Rica And Montenegro, WT/GC/W/752/Rev.2 (n 151) Annex para 1. See also Report by the Facilitator, JOB/GC/222 (n 151) Annex (adding that AB members may be assigned to a new division until 60 days before the expiry of their term). Communication from Thailand, WT/ GC/W/769 (n 151) paras 2.2-2.3 (providing that former AB members can only complete 
Significantly for the present article, several proposals for DSU amendments, or General Council or DSB decisions, have suggested creating an annual meeting between the AB and the DSB, where any WTO member could 'express its views on adopted Appellate Body reports', beyond the existing right to express a view at the time of adoption of a report. The idea is to create 'an additional "channel of communication" where concerns with regard to some Appellate Body approaches, systemic issues or trends in the jurisprudence could be voiced. ${ }^{160}$ Such proposals respond to the argument of the United States that the $\mathrm{AB}$ has become too influential vis-à-vis members. The existence of such an annual meeting would increase the opportunities for WTO members to provide feedback to WTO adjudicators, short of an authoritative interpretation, and attempt to exert informal political control over the AB. Nevertheless, some of these proposals respond to the obvious risks such a meeting could create, for example by providing that members 'shall be respectful of the independence and impartiality of the Appellate Body', and procedural rules would be adopted for such meetings 'to avoid undue pressure on Appellate Body members'. ${ }^{161}$ For example, such procedural rules could prohibit the 'discussion of ongoing disputes or any member of the Appellate Body'.162

The suggestion of an annual meeting partly resembles a proposal made fifteen years ago, by the Sutherland report on the future of the WTO, concerning the potential for the DSB 'to play a more constructive role' with regard

an appeal with the approval of the DSB but the DSB shall grant such approval automatically where the oral hearing takes place at least 30 days before completion of the outgoing member's term). Communication from the African Group, WT/GC/W/776 (n 151) para 2.2 (proposing allowing application of rule 15 for 2 years after expiry of term). Communication from Honduras, WT/GC/W/759 (n 151) (outlining various options regarding rule 15 issue). 160 Communication from the European Union, China, Canada, India, Norway, New Zealand, Switzerland, Australia, Republic of Korea, Iceland, Singapore, Mexico, Costa Rica And Montenegro, WT/GC/W/752/Rev.2 (n 151). Similarly: Report by the Facilitator, JOB/ GC/222 (n 151) Annex. Communication from Japan, Australia and Chile, WT/GC/W/768/ Rev.1 (n 151) paras 2.13-14. Communication from Thailand, WT/GC/W/769 (n 151) para 19. Another intervention in reform debates, from Honduras in February 2019, flagged the option of a review mechanism - without necessarily endorsing it - that might determine whether the $\mathrm{AB}$ had in particular instances overstepped its mandate, and could be composed either of the WTO Director-General, the DSB, selected WTO committee chairpersons, or a small committee of WTO members' representatives serving in their individual capacity: Communication from Honduras, WT/GC/W/76o (n 151) para 2.5 .

161 Communication from the European Union, China, Canada, India, Norway, New Zealand, Switzerland, Australia, Republic of Korea, Iceland, Singapore, Mexico, Costa Rica And Montenegro, WT/GC/W/752/Rev.2 (n 151). Similarly: Communication from Thailand, $\mathrm{WT} / \mathrm{GC} / \mathrm{W} / 769$ (n 151) para 19.

162 Report by the Facilitator, JOB/GC/222 (n 151) Annex. 
to criticisms of WTO jurisprudence. ${ }^{163}$ Specifically, the Sutherland report suggested occasionally selecting 'particular [adjudicatory] findings for in-depth analysis by a reasonably impartial, special expert group of the DSB, so as to provide a measured report of constructive criticism for the information of the WTO system, including the Appellate Body and panels'. The suggestion was that the report of the special expert group 'could be presented to the DSB for information, or conceivably ... adopted by the DSB', and either way 'could have an important effect on the thinking of the Appellate Body members and the panellists for future cases.' ${ }^{164}$ However, the Sutherland report stressed that any feedback mechanism should not extend to a reintroduction of a diplomatic veto over the adoption of reports, or enabling the partial adoption of reports, ideas that had been suggested by some WTO members and commentators in debates over reforms to the DSU. ${ }^{165}$ The idea of permitting partial adoption of reports has resurfaced in the current crisis, for example with the suggestion that adoption of the legal reasoning contained in a report (but not the outcome for the disputing parties) could be subject to consensus or the threefourths majority requirement for authoritative interpretations, ${ }^{166}$ or that the

163 Peter Sutherland and others, The Future of the WTO:Addressing Institutional Challenges in the New Millennium (WTO 2004) para 250.

164 ibid paras $25^{1-252}$. The suggestion made in the Sutherland Report must be distinguished from the so-called 'Dole Commission' that was proposed in the US Congress in 1995 but never adopted. The latter proposal involved creating a review body consisting of US judges that would review panel and $\mathrm{AB}$ reports that were adverse to the United States against a set of criteria that included whether the panel or $\mathrm{AB}$ had added to or diminished the rights of the United States under the relevant WTO agreements. See WTO Dispute Settlement Review Commission Act (1995) HR 1438.

165 Sutherland (n 163) paras 254-255; See Claude E Barfield, Free Trade, Sovereignty, Democracy: The Future of the World Trade Organization (AEI Press 2001) 127 (recommending enabling one-third of WTO members, representing at least one-quarter of trade amongst WTO members, to block the adoption of panel or AB reports, or alternatively to allow the decision to stand for the particular dispute but not as a precedent). 'Negotiations on Improvements and Clarifications of The Dispute Settlement Understanding on Improving Flexibility and Member Control in WTO Dispute Settlement: Textual Proposal by Chile and the United States' (14 March 2003) TN/DS/W/52, subsequently issued in revised form as TN/DS/W/89, para (b) (proposing providing an opportunity for the disputing parties to agree to remove findings from a report prior to its adoption); para (c) (suggesting that the DSB be given the power to decide by consensus not to adopt particular findings in a report).

166 Communication from Honduras, WT/GC/W/761 (n 151) para 2.3(a); Henry Gao, 'Dictum on Dicta: Obiter Dicta in WTO Disputes' (2018) 17 WTR 509, 533. 
disputing parties could be permitted to agree to exclude certain interpretations from the report before adoption. ${ }^{167}$

A range of other ideas have been floated in response to the current crisis that would more radically curtail the relative influence of WTO adjudicators, and especially the AB. For example, a discussion paper on WTO reform produced by Canada in September 2018 proposed '[d]iverting certain disputes or issues from adjudication', either through formally excluding them from jurisdiction or utilising non-binding procedures, such as mediation. ${ }^{168}$ Certain recent scholarly proposals are also aimed at keeping controversial out of adjudication. ${ }^{169}$ Jennifer Hillman, a former United States AB member, has proposed that since the majority of the complaints by the United States about the $\mathrm{AB}$ stem from the latter's decisions in trade remedy cases, one solution would be to eliminate (either permanently or temporarily) appeals in such disputes or to create a specialised appellate mechanism for trade remedy cases. ${ }^{170}$ Plainly, removing certain issues from (appellate) adjudication would scale back the relative influence of the AB and panels. Certain WTO members have also proposed clarifications that would abolish the de facto precedential effect of $\mathrm{AB}$ decisions, and permit panels to 'adopt an interpretation of a WTO provision that is different from the one developed by the Appellate Body.'171 Such a clarification would

167 Weihuan Zhou and Henry Gao, "Overreaching" or "Overreacting"? Reflections on the Judicial Function and Approaches of WTO Appellate Body' (JWT forthcoming) 18-19 $<$ https://ssrn.com/abstract=3418737> accessed 4 August 2019, (also suggesting that the disputing parties be given a power to carve out specific questions of interpretation from the terms of reference, or one-third of members present in the General Council be given a power to declare that an interpretation only applies to the current case).

168 'Strengthening and Modernizing the WTO: Discussion Paper: Communication from Canada' (24 September 2018) JOB/GC/201, 3; See also McDougall (n 133) 888-889.

169 Zhou and Gao have recently made various suggestions for excluding certain issues from the scope of WTO adjudication: Zhou and Gao (n 167) 18-19. The most radical aspect is their proposal for a mechanism that would allow parties to seek a declaration from the General Council that 'a specific issue in the dispute is politically sensitive and unresolved by WTO Members, and therefore should not be subject to the interpretation of WTO tribunals'. They suggest that if only a respondent requested such a declaration it should be adopted if supported by one-third of votes cast in the General Council. If both disputing parties requested such a declaration they suggest it should be adopted pursuant to reverse consensus: 19. Zhou and Gao's proposal seems problematic insofar as it would enable such a declaration, where supported by both disputing parties (and adopted subject to reverse consensus), to result in an issue becoming non-justiciable for the entire membership.

$170 \quad$ Hillman (n 133) 4-7.

171 Communication from Japan, Australia and Chile, WT/GC/W/768/Rev.1 (n 151) paras 2.72.8. See also: Communication from Canada, JOB/GC/201 (n 168) 4 (raising the possibility of 'reiterating that interpretations adopted by the panel and Appellate Body apply 
reduce the overall interpretative influence of the $\mathrm{AB}$ vis-à-vis WTO members. Other proposals advanced with similar aims include providing guidance that adjudicators are to prioritise giving effect to member intent, and clarifying the competing aims of WTO dispute settlement set out in the DSU, for example by removing the aim of clarifying the covered agreements. ${ }^{172}$

\subsubsection{Overall Evaluation of the Current Crisis}

What conclusions can be drawn regarding what the ongoing $\mathrm{AB}$ crisis indicates about the DSB as a voice mechanism and its relationship with judicial independence? The manner in which the United States has aggressively and effectively exercised voice has obviously been made possible by the fact that the relevant DSB decision that needs to be made to keep the $\mathrm{AB}$ operating $((\mathrm{re})$ appointment of members) must be taken by consensus. A requirement of consensus gives each member a potential veto, and thus exponentially increases the voice that a dissatisfied member can exercise. ${ }^{173}$ In contrast, in the earlier episode of member discontent, concerning the AB's decisions on amicus briefs, the membership needed to reach consensus to override the AB's decision, and as no consensus existed, the dispute settlement system continued to operate, albeit with an important signal having been sent regarding member disapproval. ${ }^{174}$ However, the dramatic exercise of voice by the United States must be appreciated in light of its immense power within the WTO. ${ }^{175}$ As others

only to the disputes in which they are adopted'); Communication from Honduras, WT/ GC/W/761 (n 151) para 2.2(a). See also paras 2.3(b)-(c) (proposals that would only establish legal interpretations by the $\mathrm{AB}$ as precedent if they are repeated a certain number of times and/or approved by members in the DSB). For somewhat different positions see: Report by the Facilitator, JOB/GC/222 (n 151) Annex (providing that '[p]recedent is not created through WTO dispute settlement proceedings' and that 'Panels and the Appellate Body should take previous Panel/Appellate Body reports into account to the extent they find them relevant'); Communication from Brazil, Paraguay and Uruguay, WT/ GC/W/767/Rev.1 (n 151) paras 6.2-6.4; Communication from Thailand, WT/GC/W/769 (n 151) paras 17-18.

172 Communication from Honduras, WT/GC/W/76o (n 151) para 2.4(b)-(c). McDougall (n 133) 889-89o. Communication from Taiwan, WT/GC/W/763 (n 151) paras 2.2-2.3.

173 Weiler, in his analysis of the early European Community, noted how the emergence of an ability of each member State to veto legislative proposals increased the voice available to individual member States: Weiler (n 50) 2423, 2427-2429.

174 Formally, the General Council could have overridden the AB through an authoritative interpretation by a three-fourths majority rather than consensus (under art IX:2 of the WTO Agreement).

175 As Steinberg has noted '[w] hile measuring power is notoriously difficult, in trade negotiations, relative market size offers the best first approximation of bargaining power': Steinberg (n 51) 347. Sacerdoti (n 133) 102-103 (suggesting while the relative market size 
have highlighted, a rule of consensus decision-making, defined as the absence of objection from any member, does not give an equal vote to every member. Instead, it 'resembles weighted voting in that it gives more weight to politically and economically powerful players', who are better able to exercise voice and influence through wielding a credible threat of a veto. ${ }^{176}$ Thus, it would be difficult for a less powerful WTO member to replicate the strategy of the United States and block $\mathrm{AB}$ appointments on a prolonged basis in the face of broad-based pressure from the rest of the membership. ${ }^{177}$

Another interesting question is what the current $\mathrm{AB}$ crisis suggests about the continuum between voice and exit in international organizations. Given the aggressive and sustained nature of the US exercise of voice, it is tempting to analogise the current situation to what Weiler referred to in the European context as 'Selective Exit', whereby although formally remaining within an organization, the disgruntled member(s) would seek to avoid their legal obligations. ${ }^{178}$ Others have suggested a similar category of 'asphyxiation', whereby a disgruntled member, rather than formally exiting a tribunal or the international organization in which it is embedded, may seek to shut down a tribunal from the inside. ${ }^{179}$ The particular institutional design features that make a strategy of asphyxiation possible is the combination of the (re) appointment of adjudicators being dependent on consensus with the rule that adjudicators' terms expire even if they have not been replaced. ${ }^{180}$ Thus, the

of the United States has declined since the formation of the WTO 'it can still effectively block the system').

176 Pauwelyn, 'Transformation' (n 52 ) 44. See also Steinberg (n 51) 342, 36o. Hirschman (n 9) 40-41 (noting 'voice is ... conditioned on ... the influence ... members can bring to bear within' an organization, and that voice is most likely to be important where a dissatisfied member of an organization wields considerable power).

177 Joost Pauwelyn and Rebecca J Hamilton, 'Exit from International Tribunals' (2018) 9 JIDS 679,689 .

178 Weiler (n 5o) 2412. Hirschman recognised a category that at first glance also seems relevant to the AB's current position, that of 'boycott' as a 'phenomenon on the border line between voice and exit': Hirschman (n 9) 86. However, Hirschman's concept of boycott was intended to refer to a situation whereby a member exited an organization temporarily, rather than simply threatening exit, while holding out the promise of re-entry if its demands were met: Hirschman (n 9) 86.

179 Pauwelyn and Hamilton (n 177) 687, drawing on 'Farewell Speech of Appellate Body Member Ricardo Ramírez-Hernández' (28 May 2018) <www.wto.org/english/tratop_e/ dispu_e/ricardoramirezfarwellspeech_e.htm $>$ accessed 4 August 2019.

180 Pauwelyn and Hamilton ( $\mathrm{n}$ 177) 689. Beyond the WTO, another example that illustrates this point is the SADC Tribunal, where Zimbabwe, dissatisfied with certain decisions of the Tribunal, prevented the reappointment of Tribunal members, and within a few years all of the judges' terms had expired. This was possible because under the relevant constituent instruments, the decision to (re)appoint Tribunal members had to be 
recent experience with the $\mathrm{AB}$ suggests that such a combination must be avoided if the aim is to design a tribunal that enjoys long-run independence, for example by providing that adjudicators can continue in office until their successors are appointed. ${ }^{181}$ The notion of asphyxiation also captures the reality that a range of indicators suggest that the United States is not seriously considering exiting the WTO, ${ }^{182}$ and is instead pursuing the narrower project of shutting down the $A B .{ }^{183}$ Such a characterisation is also consistent with the fact that while maintaining its block on $\mathrm{AB}$ appointments, the United States has not set out its own reform proposals and has responded to the reform proposals of other members - which address several of its concerns - by suggesting that 'Members need to engage in a deeper discussion of why the Appellate Body has felt free to depart from what Members agreed to.'.184

A third aspect of the current crisis concerns the reactions of other members, beyond the United States. The reform proposals advanced by other members, outlined above, suggest that there is widespread acknowledgement that it will be necessary to accommodate many of the demands of the United

made by the Summit of the Heads of State or Government of the SADC, which, unless otherwise provided, operates by consensus, and there was no provision for Tribunal members to continue serving after their term expired. See Protocol on Tribunal in the Southern African Development Community (signed 7 August 2000, entered into force 14 August 2001) art 4(4), and Consolidated Text of the Treaty of the Southern African Development Community, (signed 17 August 1992, entered into force 30 September 1993, as amended) art 10(1), (9), available via <www.sadc.int/documents-publications/> accessed 12 September 2019. For discussion of this episode see eg Karen J Alter, James T Gathii and Laurence R Helfer, 'Backlash Against International Courts in West, East and Southern Africa: Causes and Consequences' (2016) 27 EJIL 293, 311-314.

181 A proposal tabled by a few WTO members in December 2018 sought to address these issues by variously moving to a single, longer non-renewable term, allowing outgoing $\mathrm{AB}$ members to continue serving until they are replaced (for a maximum of two years), and automatically launching a selection process six months before an $\mathrm{AB}$ member's term expires: Communication from European Union, China, India and Montenegro, WT/ GC/W/753/Rev.1 (n 151).

182 For example, outside the dispute settlement context, the United States has pursued certain initiatives within the WTO, such as attempts to strengthen notification requirements under the WTO: see McDougall (n 133) 870.

183 Shaffer (n 65) 51.

184 Statements by the United States at the Meeting of the WTO Dispute Settlement Body (30 September 2019) 15 (emphasis in original; also suggesting that 'Without further engagement from WTO Members on the cause of the problem, there is no reason to believe that simply adopting new or additional language, in whatever form, will be effective' in addressing the concerns raised by the United States) <https://geneva.usmission. gov/wp-content/uploads/sites/29o/Sept3o.DSB_Stmt_.as-deliv.fin_.public.pdf> accessed 14 October 2019. 
States in order to resolve the current crisis. Notably, other WTO members have not pursued options outside the WTO minus the United States, such as the creation of a parallel appellate tribunal, an idea that was floated by some commentators. ${ }^{185}$ Certain members, such as the EU, have expressed loyalty to the $\mathrm{AB}$, based on broader ideals it is seen to represent concerning the rule of law in international (trade) relations. ${ }^{186}$ Yet reforms that would substantially strengthen the independence of the $\mathrm{AB}$ - such as moving to a single, renewable term or endorsing some form of consensus-minus-one (or minus-two) for $\mathrm{AB}$ appointments ${ }^{187}$ - have not received widespread support. ${ }^{188}$ This reflects that as well as such reforms being a non-starter with the United States, other members share, to varying degrees, the core US concern about the relative influence of adjudication vis-à-vis political processes within the WTO. ${ }^{189}$

A final aspect of the current crisis relevant to this article concerns the merits of creating an annual meeting between WTO members and the AB, unrelated to the DSB's role in particular disputes. The idea of a regular meeting that enables informal dialogue between adjudicators and member State political representatives is utilised in some other international courts and tribunals. ${ }^{190}$ However, in the WTO context, the option of an annual meeting

185 Kuijper (n 133) 9-11.

186 See eg European Union, 'Concept Paper: WTO Modernisation' (September 2018) (suggesting paralysis of the $\mathrm{AB}$ 'would equate to a 20-year step backward in global economic governance. It would mean going back to a trading environment where rules are only enforced where convenient and where strength replaces rules as the basis for trade relations.') <http://trade.ec.europa.eu/doclib/docs/2018/september/tradoc_157331.pdf> accessed 2 August 2019. Poulsen suggests that loyalty can exist in relation to organizations and such loyalty may be based on ideals that the organization is thought to represent. Poulsen (n 49).

187 Rachel Brewster, 'The Trump Administration and the Future of the WTO' (2018) 44 The Yale Journal of International Law Online 6, 14-15.

188 The additional DSU amendments aimed at strengthening the AB's independence, contained in Communication from European Union, China, India and Montenegro, WT/ GC/W/753/Rev.1 (n 151), the contents of which was explained above $n 181$, were only sponsored by four WTO members at a December 2018 General Council meeting.

189 See eg Communication from Australia, Singapore, Costa Rica, Canada and Switzerland, $\mathrm{WT} / \mathrm{GC} / \mathrm{W} / 754 /$ Rev.2 (n 151).

190 For example, the ICC, the ICJ, and the International Tribunal for the Law of the Sea all provide annual reports to their governing political organs, which are presented by the president of the relevant tribunal during an annual meeting. The ICC also has a procedure for regular 'diplomatic briefings' where the President of the Court, Prosecutor and Registrar inform the representatives of member States about recent developments and there is an exchange of views: see generally Blokker (n 2) 39-40. Godzimirska (n 1) (analysing government statements in the United Nations General Assembly concerning the annual report of the ICJ). The AB has provided annual reports since 2003: WTO, 
between the DSB and AB does not seem to add much compared to the existing option of convening a special session of the DSB to discuss particular issues. ${ }^{191}$ The key difference would be that, under the proposal, AB members would attend such an annual meeting. This seems unlikely to produce a significant change given that, by all accounts, the $\mathrm{AB}$ already follows very closely what occurs in DSB meetings, and lawyers from the WTO and AB Secretariats attend DSB meetings. Having AB members present may also create difficulties around designing procedural rules that adequately protect judicial independence.

However, the motivation behind the idea of an annual meeting, namely increasing dialogue between WTO adjudicators and members, deserves further attention. There is value in additional mechanisms than enable members to refine the content of WTO law on a prospective basis, in a manner that is detached from the outcome in specific disputes. For example, as Yuka Fukunaga proposes in her contribution to this issue, members could create a procedure for publishing and circulating via the DSB written statements on particular interpretative questions, in response to $\mathrm{AB}$ interpretations. ${ }^{192}$ This could allow agreement on particular interpretative questions to emerge among subsets of WTO members, and members to register support for existing interpretative statements, even though most such interpretations would not achieve sufficient support to constitute subsequent agreement or subse-

'Appellate Body Annual Reports' <www.wto.org/english/tratop_e/dispu_e/ab_an_rep_e .htm> accessed 2 August 2019. These are separate from the annual reports provided by the DSB pursuant to 'Procedures for an Annual Overview of WTO Activities and for Reporting Under the WTO' (24 November 1995) WT/L/105.

191 The point that special sessions of the DSB could be convened in which members could explain their views on the systemic issues that underpin the current crisis is highlighted by Creamer ( $\mathrm{n} 75) 54$.

192 Yuka Fukunaga, 'The Appellate Body's Power to Interpret the WTO Agreements and WTO Members' Power to Disagree with the Appellate Body' (2019) 20 JWIT 792, 812-18. An interesting precedent, at the level of dispute settlement procedures, is the 'Statement on a Mechanism for Developing, Documenting and Sharing Practices and Procedures in the Conduct of WTO Disputes', JOB/DSB/1 (11 July 2016). This statement created a mechanism whereby members can indicate their willingness to participate in sharing practices concerning the conduct of WTO disputes. Endorsement of this statement, or the specific procedural documents circulated pursuant to it, is without prejudice to the correct interpretation of the DSU. The mechanism has led to various subgroups of members endorsing documents dealing with different procedural practices: see JOB/DSB/1/Add.1/Rev.1 (21 August 2017). While the mechanism does not have clear legal effects, it is arguably an example of incremental, member-driven change: Chios Carmody, 'Small Changes in Big Times: The WTO's Informal Mechanism on Procedural Innovation' (2019) 1 ITLR 26, $44-45$. 
quent practice, or to enable the adoption of authoritative interpretations or amendments. ${ }^{193}$ To be constructive, and not undermine judicial independence, such a process would need to focused on the refinement by members of particular questions of WTO law, on a prospective basis, rather than on criticism of the AB. ${ }^{194}$ Accordingly, as Fukunaga suggests, such interpretative statements should not be permitted to interfere with the binding nature of panel or $\mathrm{AB}$ reports in specific cases, which would unduly undermine judicial independence. ${ }^{195}$ Finally, as part of attempts to increase dialogue between the $\mathrm{AB}$ and the membership, renewed thought may be needed regarding the other side of the equation, namely whether the $\mathrm{AB}$ or panels could be given a power to remit certain legally uncertain issues to relevant WTO committees or the DSB, for further negotiations and resolution in political fora. ${ }^{196}$

The above analysis of the key instances where the DSB has been used by members to voice dissatisfaction with WTO adjudicators' decisions demonstrates that the DSB can be used in ways that threaten judicial independence, for example if members expect that criticism of adjudicators' decisions in the DSB should lead to those decisions being reversed. More broadly, the analysis confirms Blokker's suggestion that it is difficult to design procedures that enable meaningful dialogue between international tribunals and the political bodies that oversee the governance of tribunals, and that strike an appropriate balance between judicial independence and judicial accountability to member States. ${ }^{197}$ The above analysis also demonstrates that the relationship between political and adjudicatory processes within the WTO is complex and multifaceted, and depends upon the interaction of a wide range of design

193 As Fukunaga notes such statements could nevertheless have some subsidiary value, for example as supplementary means of treaty interpretation: see Fukunaga (n 192) 812-18. Convening a special meeting of the DSB for thematic discussions, and charging the Secretariat with collecting and annotating members' statements, could also identify areas of agreement among members: Creamer ( $n$ 75) 54. However, the suggestion of written and formally circulated interpretative declarations may be preferable because they would likely be more precise and have a clearer legal status than DSB statements. See also 'Communication from Canada' (n 168) 3 (suggesting the possibility of providing nonbinding guidance that could provide a pathway to the eventual adoption of authoritative interpretations).

194 Ehlermann and Ehring (n 64) 822.

195 Fukunaga (n 192) 793-5, 812-18.

196 For such a proposal see Payosova, Hufbauer and Schott (n 133) 9. Bartels has suggested that panels and the $\mathrm{AB}$ should be given a power to suspend proceedings temporarily to allow a decision to be reached in a political forum, and even to reject cases where they would interfere with the exclusive powers of a political organ: Bartels (n 23) 894-895. Communication from Honduras, WT/GC/W/761 (n 151) para 2.3(c).

197 Blokker (n 2) 40. 
features. ${ }^{198}$ Thus, it would be misleading to suggest there is any single solution to the current crisis. Nevertheless, within the discussion over DSU reform that is ongoing, there is a need for creative thinking regarding additional mechanisms that can increase members' ability to influence the content of WTO law, even if on a non-binding basis, without unduly undermining adjudicators' independence. ${ }^{199}$

\section{5}

\section{Conclusion}

Unlike most perspectives on WTO dispute settlement that typically address the DSB in passing, this article has focused on this diplomatic body and its interaction with adjudicatory processes. Specifically, this article has analysed the 'voice' function of the DSB, suggesting that this is an important mechanism because it enables members to provide regular feedback to WTO adjudicators, and helps sustain the dispute settlement system's internal legitimacy. However, the episodes examined in this article suggest that the DSB can be used in ways that undermine judicial independence. In relation to the ongoing crisis over $\mathrm{AB}$ appointments, this article's engagement with Hirschman's framework of exit, voice and loyalty, highlights how the United States, given its immense power within the WTO, has been able to sustain a crippling veto, and has used this strategy to focus attention on a range of pre-existing complaints about the AB's performance. The reform proposals advanced by other members since mid-2018, which are almost all responsive to the concerns of the United States and would reduce the AB's relative interpretative influence, suggest that the exercise of voice by the United States has been effective.

By analysing the DSB's voice function, this article has provided one relatively specific perspective on the wider issue of the relationship between international tribunals and the political bodies that oversee such tribunals. Like other such political governance bodies, the DSB is a key site where the tension between the independence of international tribunals and their accountability to member States plays out. I suggested that while accountability to members in relation the content of adjudicatory decisions is in tension judicial independence, there are limited but significant ways in which such accountability exists in the WTO context, for example through the threat of non-reappointment in relation to sitting $\mathrm{AB}$ members or the potential for widespread criticism of decisions in DSB meetings.

198 Similarly Dunoff and Pollack (n 76$) 230$.

199 A similar point is made by Creamer (n 75$) 54-5$. 
Going forward, there a few questions arising from my analysis that would benefit from further attention, relating to whether it may be possible to develop further comparative insights through consideration of the operation of other political bodies that oversee international tribunals. Specifically, it would be worthwhile to compare the relationship between the DSB and the AB or panels to contexts where the political body that oversees an international tribunal is less formalised or meets less regularly, including where the political body is a meeting of States parties' representatives convened on an ad hoc basis. ${ }^{200}$ In this regard, an important question would be whether it makes any difference to the dynamics of adjudicatory independence and accountability that the DSB is a political body explicitly designed to oversee dispute settlement, which in comparative perspective meets very regularly and discusses adjudicatory activity in substantial detail. Another line of inquiry might consider the point made by my analysis of judicial accountability, that not all mechanisms of exercising control by member States necessarily undermine judicial independence, in relation to the interaction of diplomatic and adjudicatory elements in other international regimes. To be sure, such a comparative analysis would be challenging in its breadth, but it may also reveal new ideas relevant to the current search, against the backdrop of the crisis over $\mathrm{AB}$ appointments, for additional mechanisms to increase WTO members' influence without unduly undermining judicial independence.

200 For example, Blokker highlights that in the past decade several important declarations concerning the European Court of Human Rights were adopted through ad hoc conferences of the States parties rather than by the Committee of Ministers: Blokker (n 2) 35 . As outlined above ( $\mathrm{n} 180$ ), the SADC Tribunal was shut down through the failure to make appointments by the Summit of the Heads of State or Government of the SADC. The latter is the highest decision-making body in the SADC and is not specifically devoted to dispute settlement. 